\title{
Effects of cyanobacterial toxins on the human gastrointestinal tract and the mucosal innate immune system
}

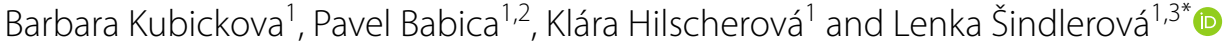

\begin{abstract}
Background: Cyanobacterial blooms occur with increasing frequency in freshwater ecosystems, posing a hazard to human and environmental health. Exposure of human to cyanobacterial metabolites occurs mostly via accidental ingestion through contaminated drinking water or during recreational activities and, most frequently, results in gastrointestinal symptoms. Despite the clinical manifestation, cyanobacterial metabolites are rather investigated for their toxicity towards specific organs or tissues, especially hepato-, nephro-, and neurotoxicity, than for effects on the gastrointestinal tract and the associated lymphoid tissue.

Main body: The aim of this review was to systematically summarize available literature on the effects on the gastrointestinal tract and the mucosal innate immune system and compile the data from both, in vitro and in vivo studies, focusing on human health-relevant models. Our systematic literature review revealed significant data gaps in the understanding on metabolites breaching the gastrointestinal barrier and the role of the immune system in the establishment of clinical symptoms. Microcystins and cylindrospermopsin were linked to gastrointestinal symptoms, immune system effects, or both. Furthermore, cyanobacterial bloom lipopolysaccharides, other less studied metabolites and their mixtures have been also implicated to have a role in gastrointestinal inflammation.

Conclusion: The collected data indicate the need for a reassessment of potential enterotoxicity of microcystins and cylindrospermopsin. In addition, the carcinogenic potential of cyanotoxins, especially microcystins, has to be clarified, as an increasing amount of epidemiological studies show correlations between cyanobacterial blooms and gastrointestinal cancer incidence. Furthermore, other, often highly abundant bioactive metabolites such as aeruginosins, have to be toxicologically evaluated at distinct levels also accounting for (sub-)chronic exposure to low concentrations and in combination with naturally co-occurring metabolites, which can be expected in drinking water supplies.
\end{abstract}

Keywords: Cyanotoxin, Cyanobacterial bloom, Cylindrospermopsin, Microcystin, Inflammation, Diarrhea, Gastrointestinal illness, Lipopolysaccharide, Innate immune system

\section{Background}

Climate change is transforming ecosystems and their composition all over the planet. Among others, temperate climates in the northern hemisphere are experiencing longer and more intense heat periods in summer and increasing $\mathrm{CO}_{2}$ levels are saturating surface waters with

\footnotetext{
${ }^{*}$ Correspondence: sindler@ibp.cz

${ }^{3}$ Department of Biophysics of Immune System, Institute of Biophysics, Czech Academy of Sciences, Královopolská 135, 61265 Brno, Czech Republic

Full list of author information is available at the end of the article
}

dissolved carbonate. In combination with other anthropogenic factors, such as eutrophication, climate changes have been linked to an increase in frequency and intensity of hazardous cyanobacterial blooms in surface waters [1-4].

Cyanobacteria, also known as blue-green algae, are photosynthetic prokaryotes of ancient origin. They are able to produce a large variety of toxic secondary metabolites, cyanotoxins, and heterogeneous in structure, activity, and stability (reviewed in Buratti et al. [5]). These metabolites can be released to water either directly 
or upon cell lysis with major implications for the directly affected aquatic species, as well as for human and livestock health. For humans, Fig. 1 illustrates the organs that are traditionally reported as targets of toxicity, as well as other organs/organ systems affected by cyanobacterial toxins.

As reviewed in Wood [6] and Stewart et al. [7], fatal poisonings of livestock and pets (e.g., dogs) have been reportedly linked to cyanobacterial blooms for decades.

Unlike animals, humans have greater capabilities to access uncontaminated drinking water (underground water or treated surface water) and tend to avoid odorous waters for drinking and recreational activities. Therefore, documented fatal human cases of acute cyanobacteria poisonings have been limited to specific exposure routes, such as hemodialysis treatment with cyanotoxin-contaminated water [8].

Nevertheless, serious adverse health outcomes have been associated also with other, more common exposure scenarios, and linked to both acute and chronic exposures to toxic cyanobacteria and cyanotoxins. During recreational water activities and sports, humans can be exposed to contaminated water by dermal contact, inhalation, and also ingestion [5]. In the most extreme cases, recreational exposure to cyanobacteria resulted in life-threatening conditions requiring hospitalization, e.g., due to atypical pneumonia [9], pneumonia followed by dyspnea and liver damage [10], or an acute hepatic failure requiring a liver transplant [11]. Gastrointestinal symptoms, including abdominal pain, malaise, nausea, vomiting, and diarrhea, were also manifested during these severe poisonings. Interestingly, such gastrointestinal symptoms have been often documented also in the other cases of acute, usually self-limited, adverse health outcomes, which followed recreational contact with cyanobacteria-contaminated water $[5,12,13]$ (see also sections below). A prospective epidemiological study found an increased incidence of gastrointestinal illnesses in human populations living in the proximity of cyanobacteria-contaminated lakes, even if their recreational contact with the contaminated water was very limited [14, 15].

Gastrointestinal irritation and diseases are regularly linked to the occurrence of cyanobacterial blooms, especially to the consumption of cyanobacteria-contaminated drinking water as reported by Levesque et al. [14, 15] and reviewed in Svirčev et al. [12]. Acute poisonings

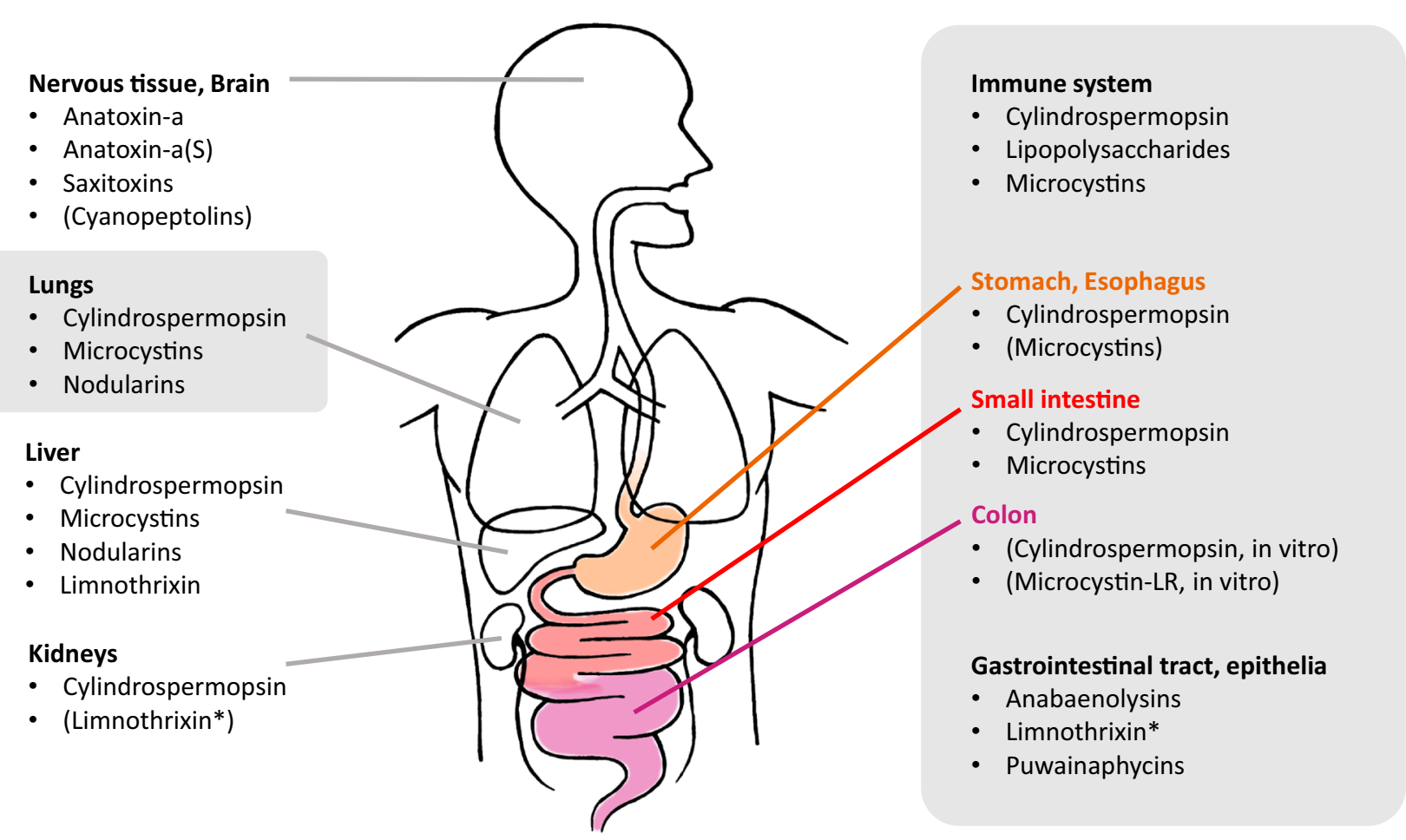

Fig. 1 Organs/organ systems affected by toxic metabolites of cyanobacteria. Organs traditionally considered targets of toxicity are on the left; organs directly subjected to oral exposure are on the right. Grey background illustrates organs with mucosal surfaces that serve as primary entry portals for environmental and dietary contaminants. The figure depicts inner organs figuratively and not anatomically correct. Data based on literature review and detailed sources are provided in Tables 2, 3, and 4. *: putative toxin, in parentheses: effect supported by in vitro data only (no in vivo data available) 
in a larger scale have been mostly reported upon consumption of insufficiently treated surface water, often following algicidal treatment of cyanobacteria-infested freshwater reservoirs used as drinking water sources [16, 17]. Lysis of cyanobacterial cells upon algicidal treatment releases the intracellular toxic metabolites to the water. While the conventional treatment technologies can eliminate intact toxic cyanobacterial cells effectively, these technologies have limited capability for removal of dissolved cyanobacterial toxins, which allows that these reach human populations via drinking water supplies in sufficiently high concentrations to cause adverse effects in the gastrointestinal system (Table 1). Chronic exposures to drinking water contaminated with cyanobacterial compounds, in some instances in combination with other confounding factors, have been associated with an increased incidence of liver cancers or chronic liver damage and diseases, as reviewed and discussed by Svirčev et al. [12], and supported by recent findings [18-20]. Interestingly, epidemiologic studies have also linked chronic exposures to drinking water contaminated with cyanobacteria and their metabolites to the increased incidence of colorectal or small intestinal cancer in China [21], Portugal [22], and Serbia [12, 23], or stomach cancer mortality in China [24]. Nevertheless, other studies have not observed strong associations between colorectal cancer and (chronic) exposures to toxic cyanobacteria [25], or found negative correlation for small intestinal cancer [24].

\section{The gastrointestinal system and its link to the immune system}

Upon oral exposure, which is the most relevant route of exposure to cyanobacterial metabolites [47], gastrointestinal epithelia are the first barrier to be overcome before systemic exposure, and hence, the gastrointestinal tract is a major entry portal for cyanobacteria and their bioactive metabolites into an organism's system. In addition, the gastrointestinal system is highly associated with the immune system. Besides harboring commensal microbiota, ingested foodstuffs, pathogens, and environmental contaminants pass through the intestines which induce the production of many toxic or antigenic compounds that may trigger inflammatory responses. To maintain a homeostatic environment and prevent exaggerated immunological reactions when inappropriate, there are several gut-specific adaptations from all compartments involved: the intestinal epithelium, the gut-associated lymphoid tissue, and the microbiome.

Interactions between the microbiome and the mucosal immune system or the gastrointestinal tract (GIT) play a critical role in the tolerance of intestinal microbiome and its specific antigens by host-defense systems to avoid permanent inflammatory states [48]. There are indications that exposure to the cyanobacterial toxin microcystin-LR alters the taxonomic composition of the microbiome, as well as the expression of functional genes in the GIT of mammals (mice, rats) $[49,50]$.

Anatomically, the gastrointestinal passage consists of the esophagus terminating into the stomach that connects via the pylorus to the small intestine (duodenum, jejunum, and ileum in descending order) [51]. While the highly active small intestine is characterized by structured epithelia with maximum surface area, the colon is less structured and lined by a thick mucus layer enabling effective water reabsorption while preventing tissue invasion of the essential commensal microbiota that reside predominantly in this part of the GIT [51, 52].

How do the GIT and the immune system accomplish the task of protective immunity and pathogen clearance while tolerating commensal microbes and dietary constituents? In the colon, the mucus secreted by the epithelial goblet cells is antimicrobial and, therefore, poses a physical barrier for bacteria ([51] and references therein). The mucus production is controlled by soluble immune mediators also known as cytokines. Cytokines can be secreted by epithelial or immune cells and modulate the immune response. For example, tumor growth factor-beta (TGF$\beta)$ and retinoic acid promote regulatory T-cell (Treg) differentiation in the gut, responsible for the homeostatic equilibrium in the intestines to a large extent [52-54]. On the other hand, pro-inflammatory interleukin (IL) IL-1, IL-6, and tumor necrosis factor-alpha (TNF- $\alpha$ ) are released by phagocytic cells upon activation of Toll-like receptors (TLRs) sensing pathogen-associated molecular patterns (PAMPs).

Intestinal phagocytic macrophages residing in the gut mucosa are sessile and they constitutively produce high amounts of (anti-inflammatory) IL-10 enabling them to limit the inflammation via effective scavenging [55]. Meanwhile, dendritic cells are mobile and act as major antigen-presenting cells migrating to secondary lymphoid organs and priming $B$ and $T$ cells that they can be recruited to the gut-associated lymphoid tissue and eventually secrete the protective immunoglobulin A into the lumen [55].

These integrated mechanisms, spatially restricted to the intestinal proximity, allow the immune system to remain unresponsive to commensal microbiota and dietary constituents in the gut lumen and to launch a robust immune defense reaction when these microorganisms or compounds cross the epithelial barrier and invade tissues and the organism. 
Kubickova et al. Environ Sci Eur $\quad$ (2019) 31:31

Page 4 of 27

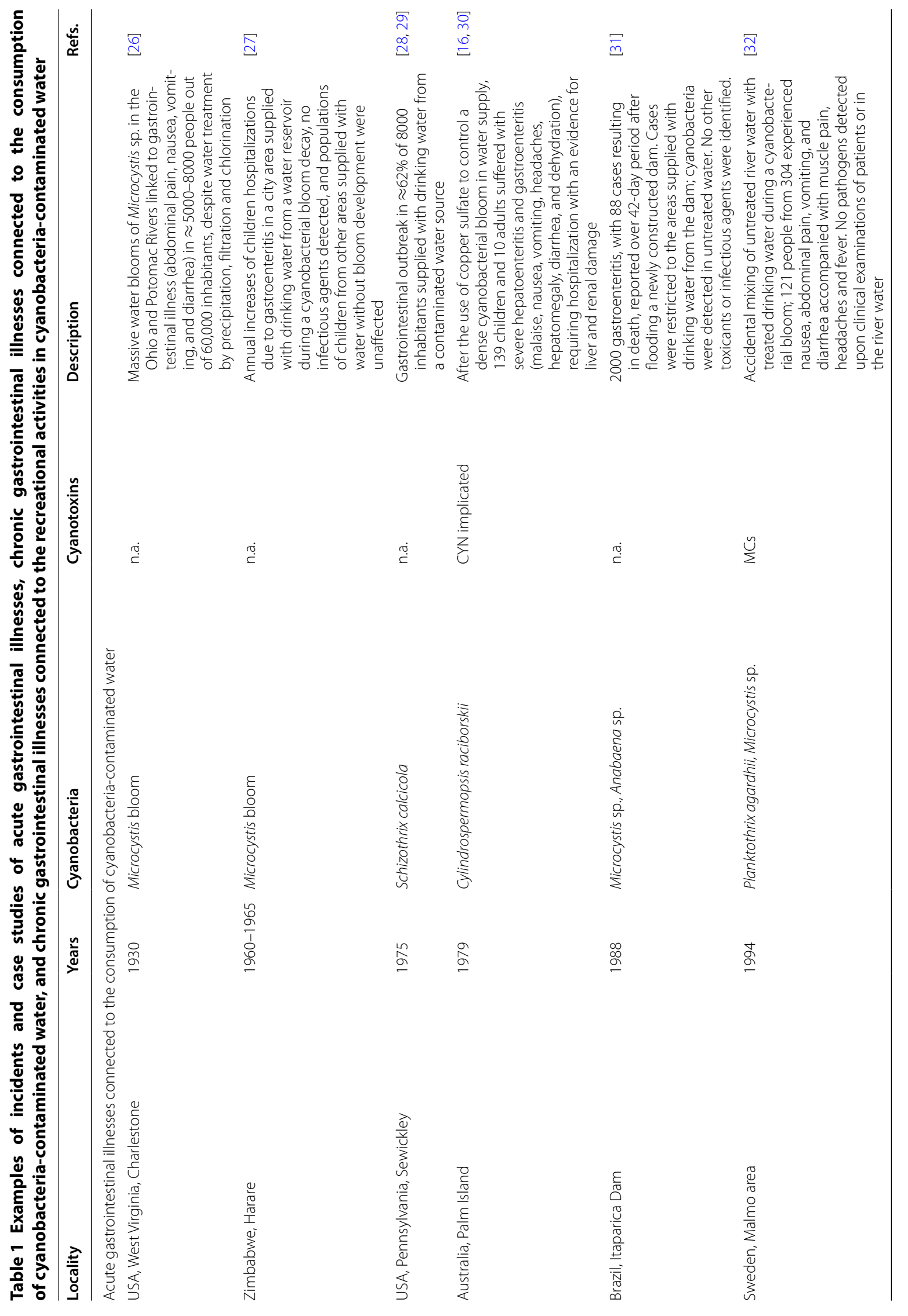




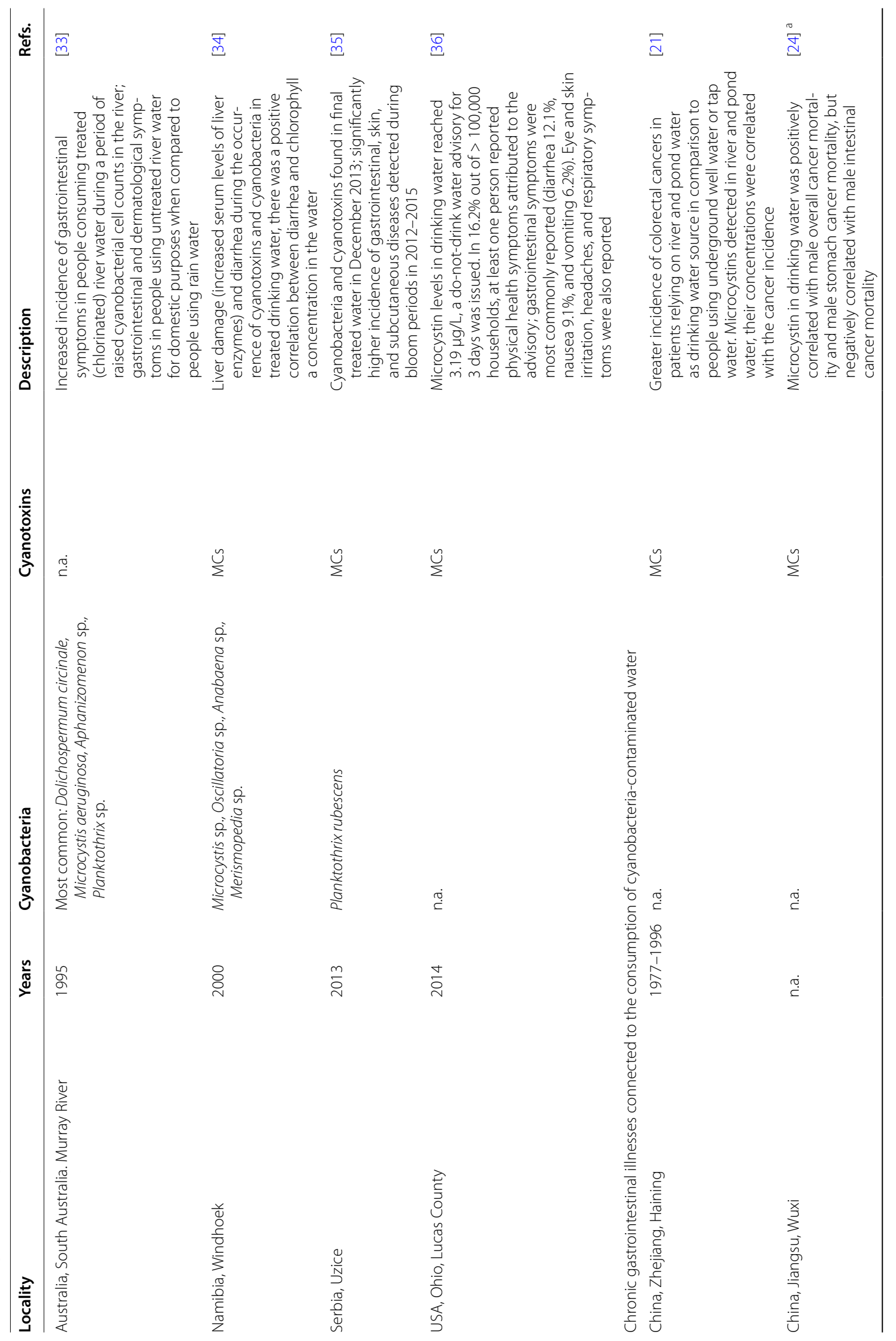


Kubickova et al. Environ Sci Eur $\quad$ (2019) 31:31

Page 6 of 27

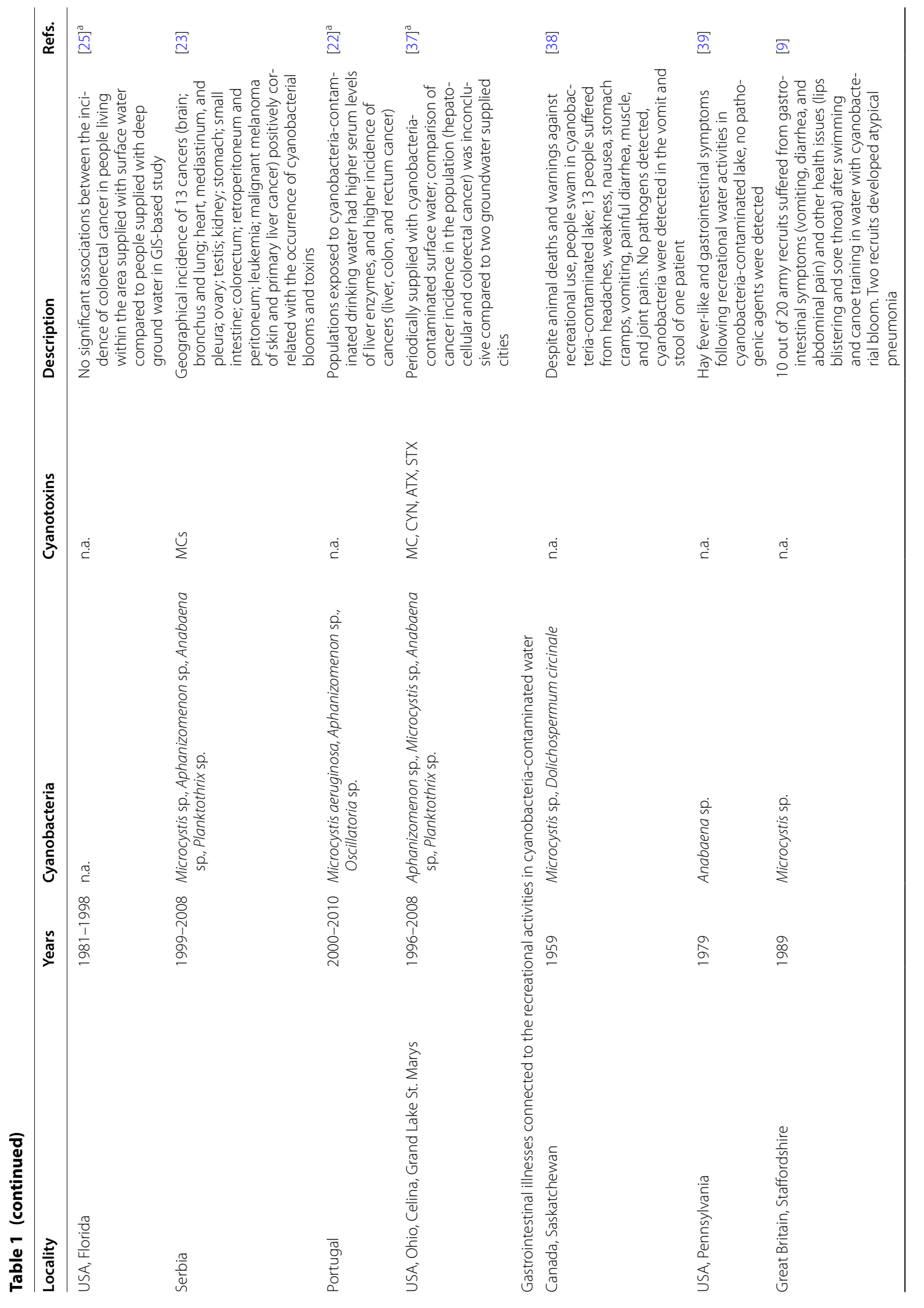




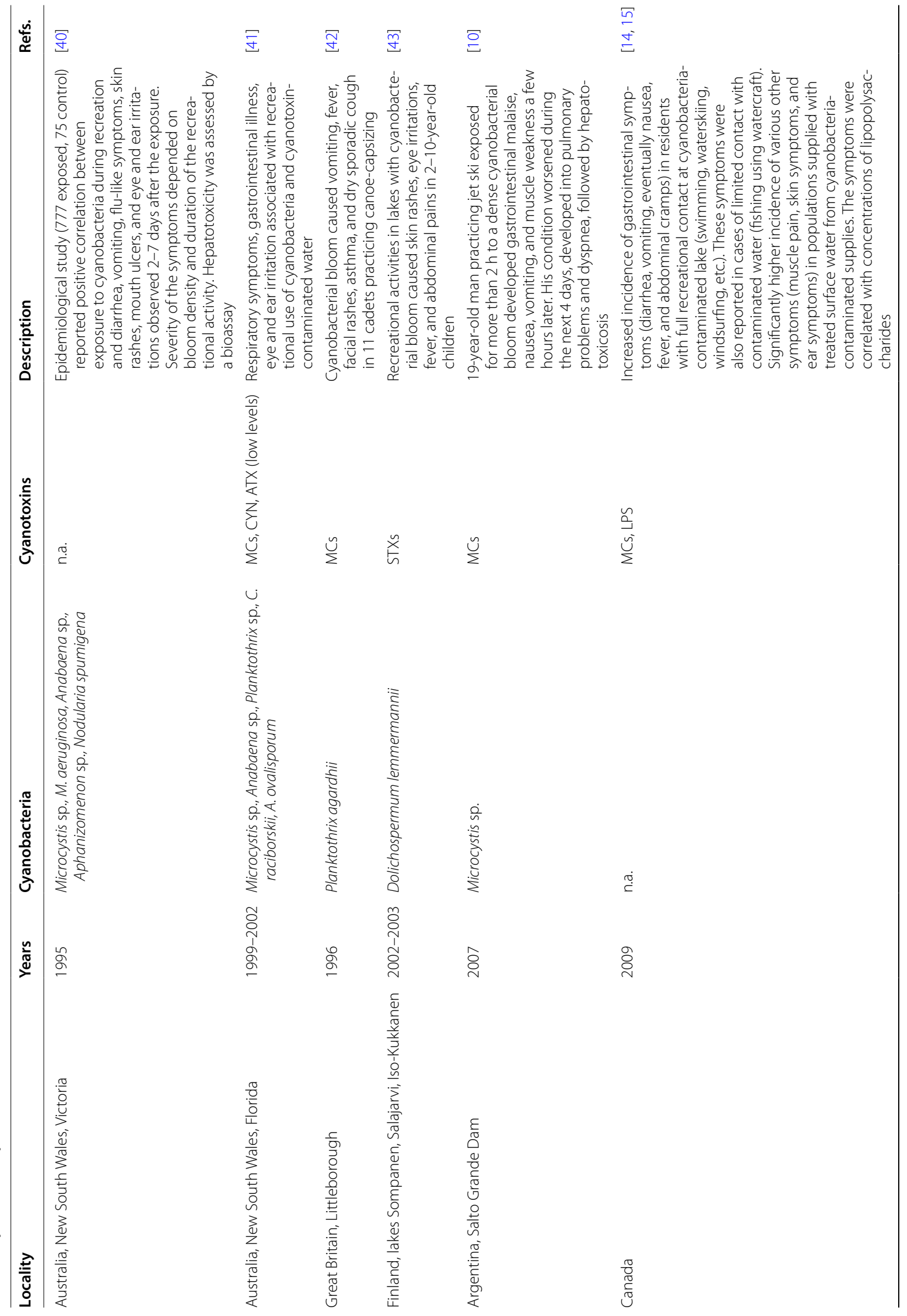




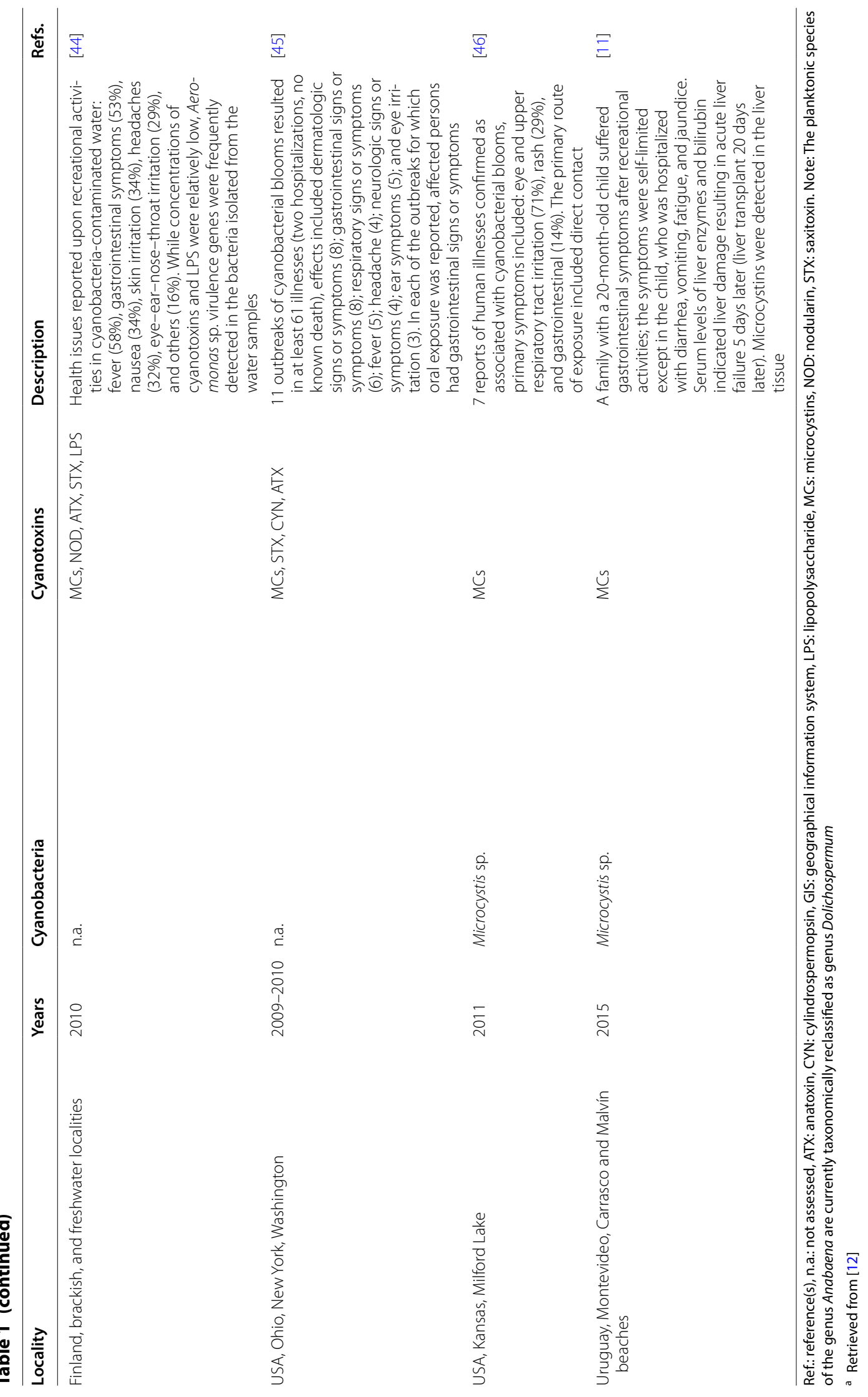




\section{Microcystin effects}

Microcystins (MCs), non-ribosomal cyclic heptapeptides, are the most common toxins in cyanobacterial blooms and the most extensively studied cyanotoxins (reviewed in Testai et al [56] and Buratti et al. [5]). MCs are synthesized via non-ribosomal polyketide/peptide synthetase multienzyme complexes encoded by the $m c y$ gene cluster. The general structure of MCs is a cyclo (-D-alanine ${ }^{1} \quad-\mathrm{L}-\mathrm{X}^{2}$-D-erythro- $\beta$-methylaspartic $\mathrm{acid}^{3}$ $-\mathrm{L}^{-} \mathrm{Y}^{4} \quad$ Adda $^{5}-\mathrm{D}$-glutamate ${ }^{6}-N$-methyldehydroalanine $\mathrm{C}^{7}$ ). Adda represents (all- $S$,all-E)-3-amino-9-methoxy-2,6,8trimethyl-10-phenyldeca-4,6-dienoic acid, which is a unique feature characteristic for all MCs. Variable L-amino acids can be present in positions 2 and 4, for example leucine (L) and arginine (R), and this structural variant is then called microcystin-LR (MC-LR). More than 240 structural variants of MCs have been reported, differing not only in the amino acids at positions 2 and 4, but also other modifications, such as demethylations of $N$-methyldehydroalanine, methylaspartic acid, or Adda [57].

Due to their hydrophilic nature, MCs cannot readily enter the cells of exposed organisms, but require an uptake mechanism. Upon swallowing, MCs overcome the gastrointestinal epithelial barrier and enter blood circulation [58-61]. Uptake into hepatocytes is facilitated by organic anion transport polypeptides (OATPs) of the bile acid transport system, particularly OATP1B1, 1B3 that are highly expressed in parenchymal hepatocytes, and also by OATP1A2 [62, 63].

Of the 12 identified OATPs, only few (OATP1B1, 1B3, $2 \mathrm{~B} 1$, and 1A2) have been extensively studied due to their expression in the tissues recognized as the main target of MCs toxicity $[64,65]$. Of these four OATPs, only OATP2B1 that is not involved in the uptake of MCs seems to be functionally relevant in the intestines, while the expression and function of MC-transporting OATP1A2 in the intestines is still being discussed [63-66]. The expression of OATP1B1 and 1B3 is considered specific to the liver [64], and hence, their contribution to the intestinal uptake of MCs is probably negligible. Other OATPs functionally expressed in the human intestinal tract are OATP4A1, 3A1, and 2A1; however, these have not been examined for their involvement in $\mathrm{MC}$ uptake [63, 64, 67]. Similarly to the GIT, cells of the innate immune system only express a limited set of OATPs. Transcriptomic analyses revealed high expression of OATP2B1 mRNA and lower levels of OATP3A1, 4A1, and 4C1, while no transcriptomic indication for OATP1A1, 1A5, 1B1, 1B2, $1 \mathrm{~B} 3$, or $1 \mathrm{C} 1$ expression in human macrophages was found [68-70]. Furthermore, functional studies on drug transport via OATP2A1 and 2B1 in human macrophages indicate their functional expression [71, 72]. Moreau et al. [68] also reported intermediate-to-low expression levels of OATP3A1 and 4C1 in monocytes, but their role in MCs cellular uptake is unclear.

Once inside the cells, MCs inhibit the ubiquitous protein phosphatases 1 and $2 \mathrm{~A}$ (PP1/2A) due to the interaction of Adda-methyldehydroalanine moiety with the catalytic site of the enzyme, including a covalent binding between methyldehydroalanine of MCs and cysteinyl residue at the catalytic site of the enzyme [5]. The consequence of protein PP1/2A inhibition by MCs is hyperphosphorylation of cytoskeletal proteins, disruption of intracellular signaling, inhibition of DNA repair, mitochondrial alternation and oxidative stress, DNA damage, apoptosis, and necrosis induction [5, 73]. Protein phosphatases play a crucial role in the intracellular signaling by dephosphorylating, and thereby deactivating, proteins like Raf, MEK, and AKT (PP2A, action as tumor suppressor) [74]. Furthermore, MC-LR has been shown to stimulate pro-inflammatory cytokine production in murine macrophages (RAW264.7) in a phosphatase-independent manner via activation of TLRs [5, 69], and promote tumor growth and possibly neoplastic transformation and carcinogenesis [75-77].

With more than 240 congeners, MC-LR is considered to be one of the most common, abundant and toxic structural variants, with a median lethal dose (LD50, acute oral toxicity) of $5-\mathrm{mg} / \mathrm{kg}$ bodyweight (bw) of orally exposed mice and a no-observed adverse effect level $\left(\mathrm{NOAEL}_{\text {liver }}\right)$ of $40 \mu \mathrm{g} / \mathrm{kg} /$ day for 13 weeks of repeated dose exposure (chronic toxicity) [2, 47, 78-82]. Modifications of MC molecules, including modifications of Adda-methyldehydroalanine region as well as other parts, such as variable amino acid residues at positions 2 and 4, can lead to the reduction of PP1/2A inhibition potencies [62, 63, 83-87]. However, the observed differences in acute in vivo toxicity of MCs [87] cannot be exclusively attributed to the differences in PP1/2A inhibition among different $\mathrm{MC}$ variants. OATP-mediated cellular uptake of MCs seems to be also structure-dependent, which contributes to the differences between cytotoxicity of individual structural variants without a clear relationship to PP1/2A inhibition potency [62]. MCs are detoxified by conjugation with glutathione (GSH) which is catalyzed by the activity of biotransformation enzyme glutathione-S-transferase. Reaction is followed by MCGSH conversion by gamma-glutamyltranspeptidase and then cysteinylglycine dipeptidase into MC-cysteine conjugate. This biotransformation reduces cellular uptake of the toxin and/or facilitates its excretion that most likely occurs via P-glycoprotein or multidrug resistance proteins, and, hence, alters the ability to inhibit PP1/2A and decreases toxicity $[85,88,89]$. 
Depending on the MC congener, the dose, and the duration of exposure, MCs cause necrotic, apoptotic, or cell-proliferative changes [90, 91]. Due to the high abundance of OATP1B1 and 1B3 in parenchymal hepatocytes, the high metabolic activity, and detoxifying function, toxic effects often manifest in the liver, even though the first site of action upon water-borne contaminants is probably mucosal epithelia of the GIT (Table 2). In fact, oral exposure of mice to MC-LR caused erosion of surface epithelial cells of the small intestine and accumulation of MC-LR in intestinal villi (Table 2) [89]. DNA damage in mice intestine and colon after intraperitoneal exposure was reported [92], as well as increased apoptotic indices in different parts of the murine intestine [93]. In both small and large intestines (caecum), MC-LR was detected in the mucus of goblet cells, indicating the excretion of MCs into the GIT lumen upon blood circulation and exposure of the liver. Similarly, Falconer [94] reported lesions in the liver and the small intestine upon oral administration of MC-containing water to pigs. Furthermore, not only epithelial lesions but also decrease in intraepithelial lymphocytes in the intestine was shown in a murine model [95]. Moreover, changes in the activity of membrane enzymes and in the peroxidation status in rat intestine were proven [96].

Besides uptake from the GIT, lesions of the small intestine (i.e., the jejunum) have been reported in mice upon intraperitoneal exposure, indicating toxic mechanisms of the MC-LR excretion into the GIT [93]. Thus, in addition to the liver, the intestines should also be considered a target of MC toxicity $[97,98]$. Besides acute effects on animals and human colon-derived cell lines, the intestines can be dietary exposed to low doses of MCs, so chronic exposure may adversely affect intestinal tissue [98].

To better mimic the human GIT and to account for interspecies extrapolation, a limited number of experiments on human gut-derived cell lines, especially the human colon carcinoma-derived cell line $\mathrm{CaCo}-2$, which exhibits properties of the small intestine upon in vitro differentiation, were conducted [99]. Zegura et al. [98] even observed a comparable sensitivity of $\mathrm{CaCo}-2$ and hepatic HepG2 cells to MC-LR exposure. Studies with CaCo-2 cells confirm a rapid uptake of MC-LR in apical-basolateral direction over a CaCo-2 monolayer [100] and indicate the susceptibility of intestinal epithelia to MC toxic effects, as observed in aforementioned in vivo studies [93]. Among others, cytotoxicity of MCs is accompanied by oxidative stress (lipid peroxidation induction, reactive oxygen species production, reduced glutathione content, etc.) and cytokine production [97]. Interestingly, MC-LR induced the same levels of IL- 6 but much higher levels of IL-8 than MC-RR in CaCo-2 cells after 24-h exposure [101]. Transcriptomic analysis showed quite similar profiles induced by MC-RR and MC-LR, but overall gene expression was higher in the case of MC-LR [102]. Interestingly, the uptake of these two congeners does not differ in $\mathrm{CaCo}-2$ cells and both of them are able to enter into the nucleus [103]. Furthermore, MCs cytotoxicity could depend also on the presence of more hydrophobic amino acids in the molecule. The more hydrophobic congeners MC-LF and MC-LW displayed higher cytotoxicity in $\mathrm{CaCo}-2$ cells in comparison to MC-LR [91].

Microcystin also plays a role in neoplastic transformation in intestinal cells. It constitutively activates AKT and p38, and JNK and MAPK pathways in human-immortalized colorectal crypt cells (NCC) which leads to their proliferation and anchorage-independent growth phenotype [77]. MC-LR also increases the migrative and invasive potential of HT-29, DLD-1 and SW480 human colon cell lines [104]. Higher migration and tissue invasion of HT-29 cells after MC-LR treatment are also connected with an increase in cadherin-11 expression [105]. Furthermore, MC-LR decreases E-cadherin expression and increases the expression of vimentin and Snail in DLD-1 and HT-29 cells promoting epithelial-mesenchymal transition [75]. A recently published study shows the ability of MC-LR to contribute to the migration of DLD-1 cells via changes in microRNA-221 expression and STAT3 phosphorylation [106].

Besides reports of effects on gastrointestinal and hepatic cells, MC-LR is suspected to alter the immune response, especially in fish, in which most of the studies addressing immunotoxic effects have been done [107-111]. For example, exposure to MC-LR affected the immune response of medaka fish and induced sustained pathological changes in the GIT, liver, and other organs [108]. Using mouse as a mammalian in vivo model, MC-LR has been shown to decrease levels of intraepithelial lymphocytes, thus affecting mucosal immunity [95]. In vitro exposure of murine macrophages to MC-LR significantly altered the expression of pro-inflammatory genes and the release of cytokines (Table 2) $[69,112]$. Adamovsky et al. [69] additionally proposed a receptor (TLR)-mediated mechanism of macrophage activation. As their model lacked specific transmembrane transporters (OATPs), the common mode of MC-LR uptake and action cannot be taken into regard. Besides the tumorpromoting potential of MCs, chronic inflammation itself plays an important role in early carcinogenesis, which, thus, may act synergistically with MC tumor promotion and neoplastic transformation potential and promote tumor progression [113]. This is of special importance considering a reported tumor-promoting and neoplastic transformation potential of MCs [75-77, 82, 114].To summarize the effects of MCs, we conclude that MCs pose a hazard to the human GIT and the associated 


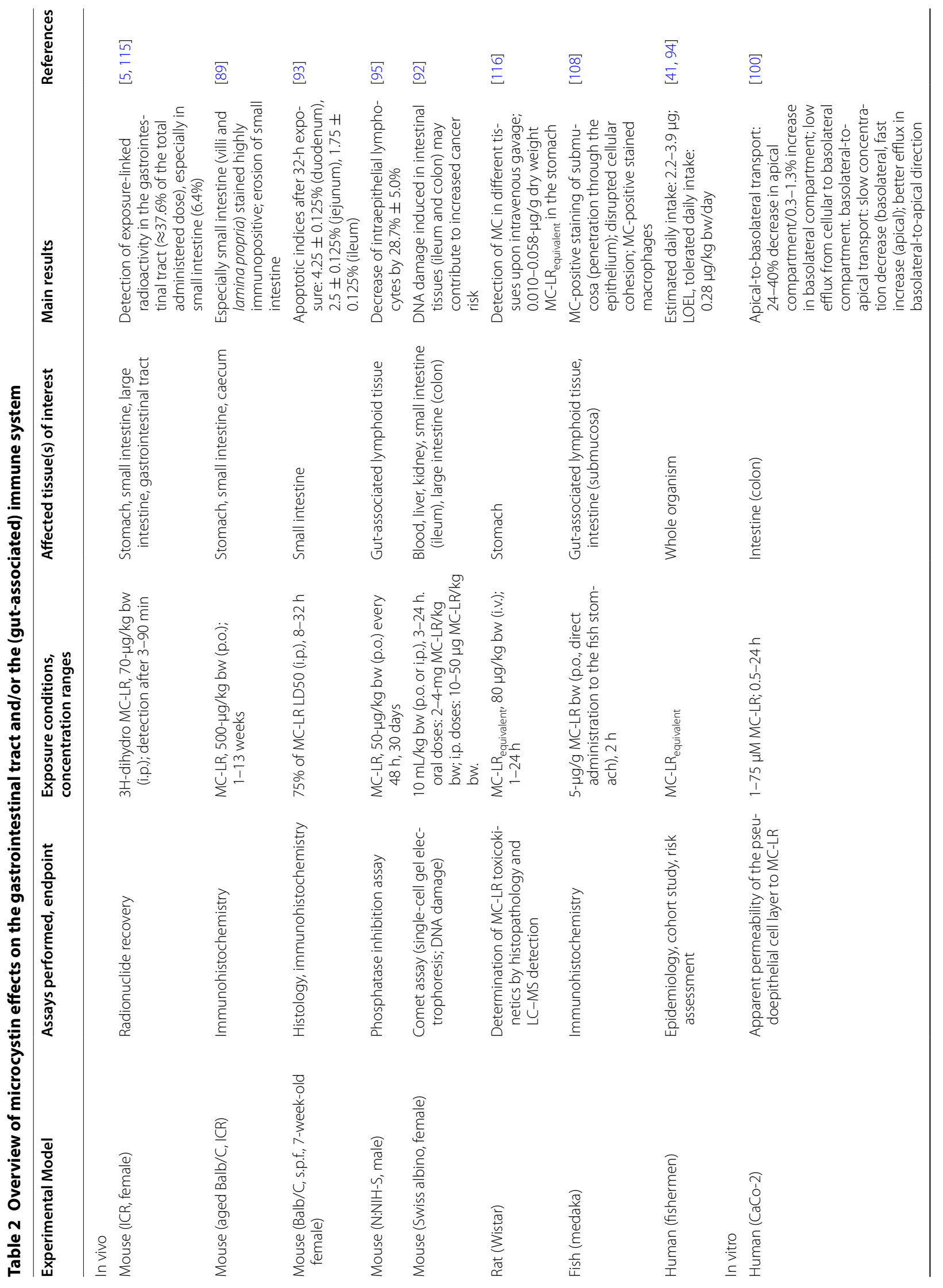


Kubickova et al. Environ Sci Eur $\quad$ (2019) 31:31

Page 12 of 27

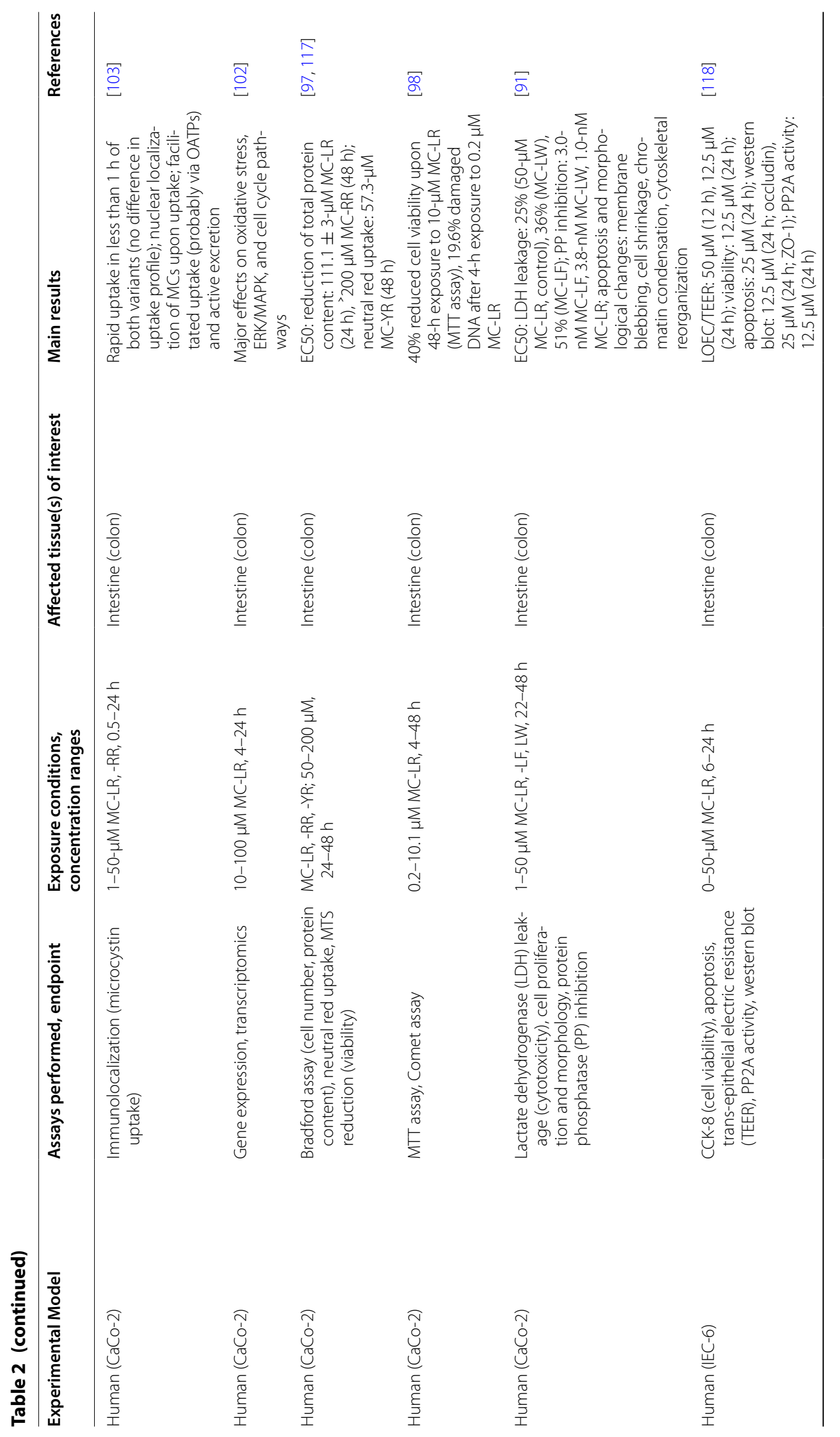


Kubickova et al. Environ Sci Eur $\quad$ (2019) 31:31

Page 13 of 27

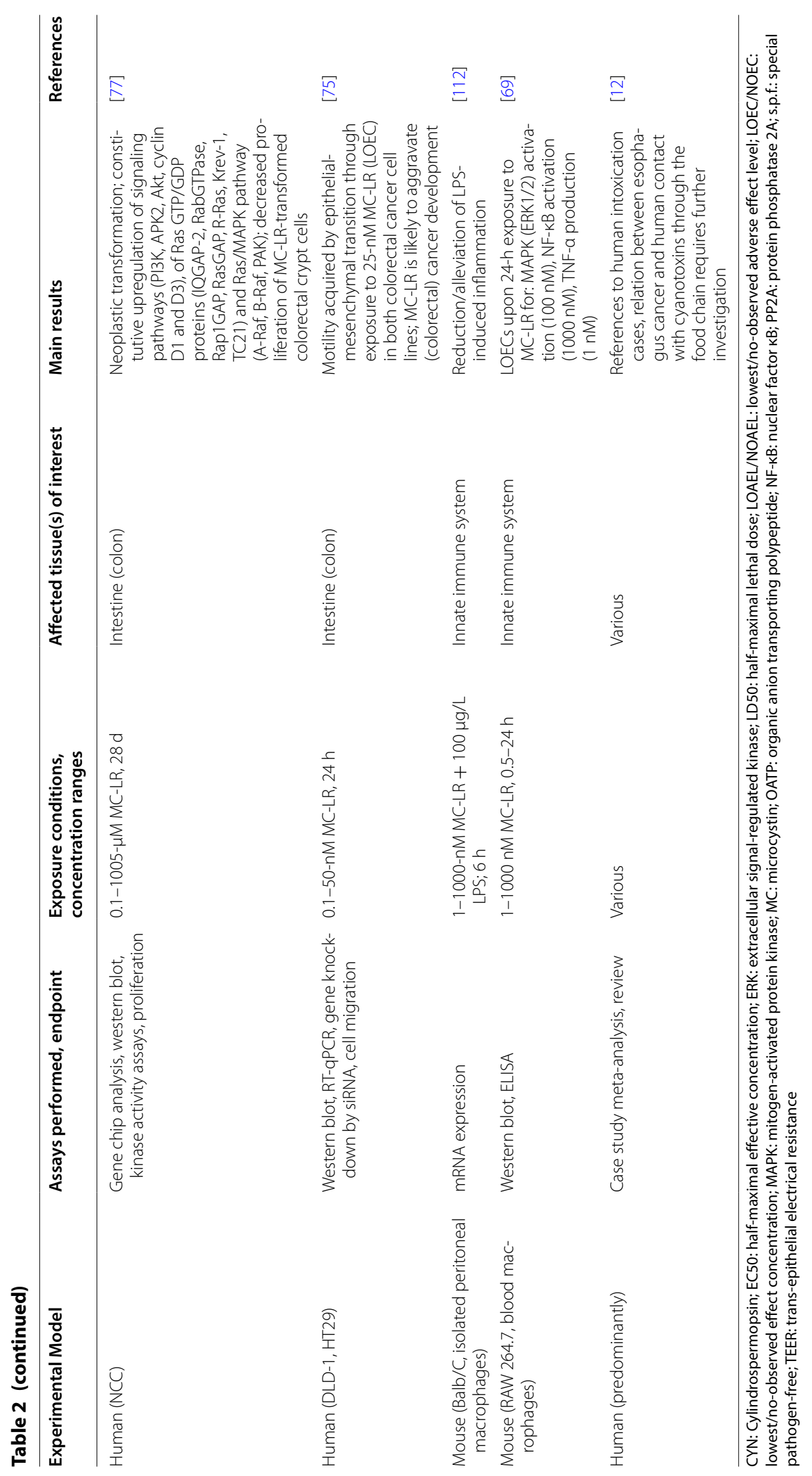


immune system; however, further experimental data are needed for quantitative effect estimation and risk assessment. The reports on epithelial damage and inflammation also suggest that MCs may sensitize the tissue for other compounds or lead to a breach of the epithelial barrier and consequently to systemic toxic effects. This is especially important as MCs seldom occur on their own and the environmental mixture of cyanobacterial bloom metabolites may act synergistically on the GIT.

\section{Cylindrospermopsin effects}

Cylindrospermopsin (CYN), a tricyclic guanidine alkaloid was first characterized in Cylindrospermopsis raciborskii [119] upon a major intoxication event in Palm Island, Australia [16]. Despite the still not entirely elucidated molecular mode of action, CYN is proven to be a potent inhibitor of protein synthesis (LOEC $=0.5 \mu \mathrm{M}$ CYN, primary mouse hepatocytes) $[5,120,121]$. In addition, CYN has been found to induce tissue damage, cytotoxic effects, oxidative stress, and DNA damage in a variety of organs and cell types [as reviewed in 120].

CYN toxicity was reported to be attenuated by different inhibitors of cytochrome P450 (CYP450) in vivo [122], as well as in the cultured cells in vitro [121, 123-127]. Induction of CYP450 activity also increased CYN toxicity in hepatic cell lines $[121,126,128]$. Thus, it has been proposed that CYP450 activity is responsible for CYN bioactivation, increasing especially $\mathrm{CYN}$-induced acute cytotoxicity, oxidative stress, and genotoxicity, while inhibition of protein synthesis appeared to be unaffected and attributed to the parental compound [121, 125]. However, no biotransformation products of CYN have been detected upon incubation with S9 liver fraction or in the presence of metabolically competent liver cell lines [127], in addition, the S9 liver fraction was not found to increase genotoxic potential of CYN in the other studies $[129,130]$. Thus, the exact role of CYP450 in CYN toxicity is not completely clear and should be investigated in the future [120]. Phase II detoxification of CYN is supposedly mediated via glutathione conjugation and excretion in the liver and kidney $[5,120,124,127,128]$. These detoxifying and excreting organs are also the most sensitive tissues (NOAEL $=30 \mu \mathrm{g} / \mathrm{kg} /$ day; in mice) and the major recipients of CYN toxicity, but adverse effects on the stomach, the small intestine, and on white blood cells have also been reported [131-133].

CYN exposure led to elevated markers of inflammation and diminished the uptake of bacteria into phagocytes in the common carp (Cyprinus carpio) [109]. Although there are significant differences between immune systems of different groups of animals, vertebrates share some common mechanisms of innate immune system activation. These first-line defense mechanisms are, amongst others, increased expression of pro-inflammatory cytokines (e.g., IL- 6 and TNF $\alpha$ ), production of reactive oxygen species (ROS), secretion of nitric oxide, and phagocytosis [69, 134-136]. Recently, it was elucidated that CYN activates murine macrophages in vitro [137]. In addition, CYN $(0.1 \mu \mathrm{g} / \mathrm{L} ; 0.24 \mu \mathrm{M})$ has been shown to significantly decrease lymphocyte proliferation in vitro in both isolated T-cell culture and a whole-blood assay [138].

Due to the hydrophilic zwitterionic nature of CYN, similarly to MCs, it probably cannot be readily absorbed from the gastrointestinal tract upon ingestion, the main pathway of human exposure, and hence, it has been hypothesized to require a facilitated or active transport $[139,140]$. Exposure of mice to CYN-induced ulcers in the stomach, and bleeding into the stomach and small intestine (Table 3) [133]. Nevertheless, there is a lack of research addressing the gastrointestinal effects of CYN. Only two studies on colon-derived tumor cells $(\mathrm{CaCo}-$ 2) address uptake kinetics across the intestinal epithelium, both reporting only a limited passage of the toxin through the intact epithelium [99, 141]. Pichardo et al. concluded that paracellular diffusion is the most likely uptake mechanism of CYN from the intestinal lumen, while active transport via P-glycoprotein or multidrug resistance proteins probably contributes to the secretion and elimination of CYN [141]. Despite the observed in vitro uptake across the epithelial barrier of intestinal cells, CYN causes oxidative stress and decreases the viability of $\mathrm{CaCo}-2$ cells in a dose-dependent manner (Table 3), highlighting that enterocytes, as well as hepatocytes, also should be considered a major important recipient of CYN toxicity, especially upon oral exposure [142].

\section{Lipopolysaccharide effects}

Like most of the commensal and pathogenic bacteria, cyanobacteria are usually Gram-negative bacteria (i.e., do not stain purple with Gram's stain). However, although there is an overall Gram-negative structure, the peptidoglycan is thicker in cyanobacteria compared to Gramnegative bacteria [147]. This group of microbes shares a common structural feature: they incorporate lipopolysaccharides (LPSs) in their cell wall. Eubacterial LPS are known as a model ligand of the Toll-like receptor 4 (TLR4), a member of pattern recognition receptor (PRR) family expressed on epithelial, endothelial, immune (particularly macrophages and dendritic cells), and other cells being an important part of the innate immunity [148-150]. To maintain homeostasis in exposed tissues, activation of PRRs may launch a robust immune reaction, eventually preventing the invasion of microbes into other tissues of a healthy individual $[151,152]$. 


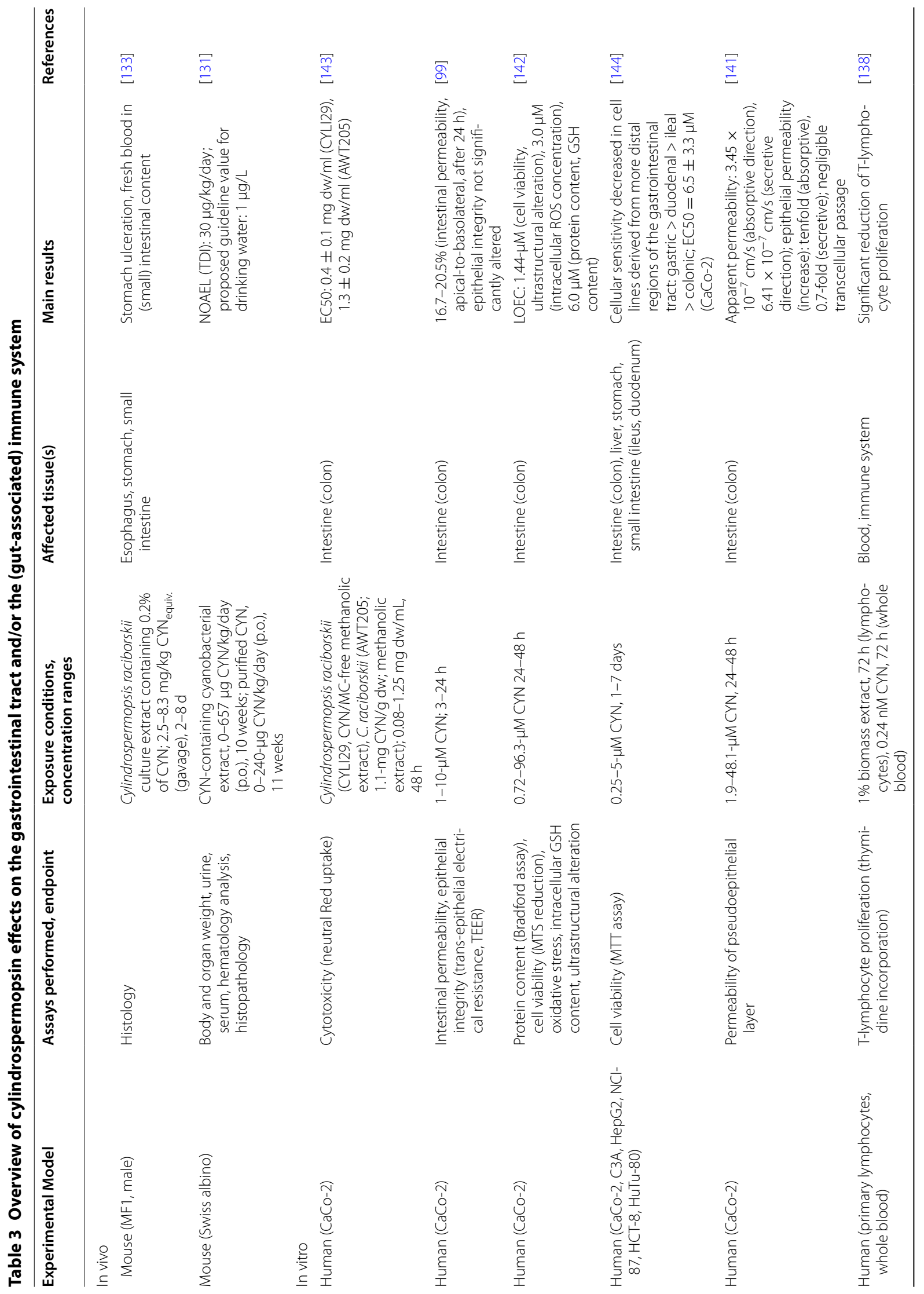




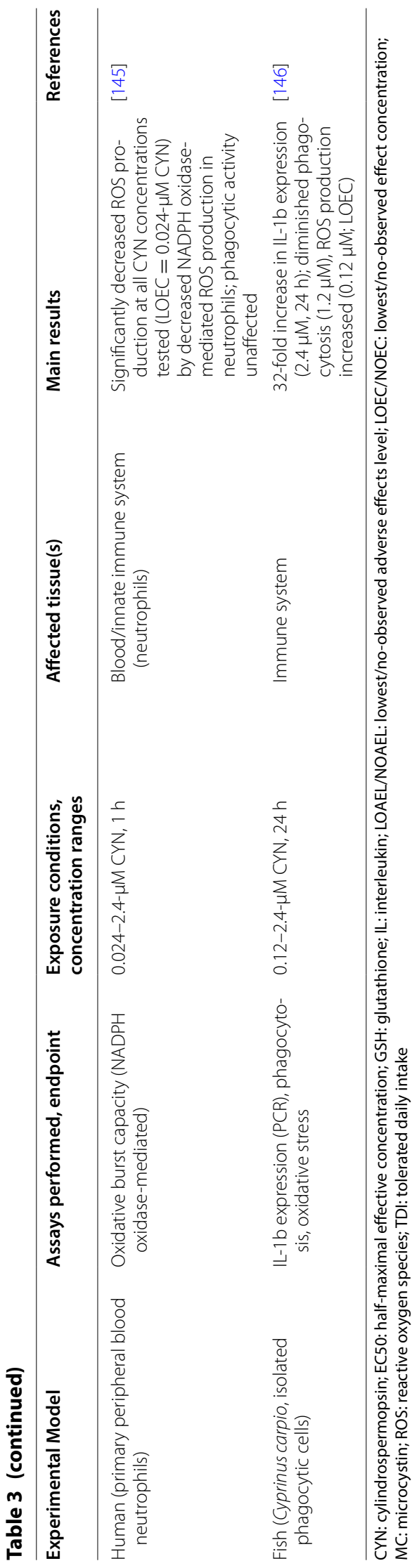


Cyanobacterial LPS was for the first time isolated and analysed by Weise and colleagues [153]. Later, some cyanobacterial LPS, e.g., from M. aeruginosa, Anabaena cylindrica, and Oscillatoria brevis, were shown to be lethally toxic for mice [154, 155]. Moreover, different human health effects connected with cyanobacterial LPS were published, including irritation of GIT, skin, eyes, and the respiratory tract. Furthermore, headache, dizziness, and fever were observed (reviewed in [156]).

Although the effects of Escherichia coli LPS are stronger, LPS from blooms and cultured strains of $M$. aeruginosa as well activates NF- $\mathrm{kB}$ in human immune cells and subsequently leads to the production and release of pro-inflammatory cytokines [157, 158]. On the other hand, LPS have also showed anti-inflammatory properties. LPS extracted from Oscillatoria planktothrix FP1 (so-called CyP) has been shown to selectively antagonize LPS from bacteria via binding to MD-2 protein [159]. CyP inhibits the production of pro-inflammatory cytokines and affects microRNA expression in different in vitro models $[160,161]$.

The different biological potential of LPS from various sources can be connected to its structural variation [162, 163]. For example, keto-deoxyoctulosonate and heptoses are absent in LPS produced by Anabaena spp. and its lipid A lacks phosphorylation and glucosamine, while being acylated at up to ten sites [155, 164-166]. Altered acylation of LPS significantly influences the magnitude of LPS inflammatory potential with hexaacylation triggering the strongest pro-inflammatory responses $[162,167]$.

One of the first and most widespread human acute health effects upon (accidental) ingestion and intoxication of cyanobacterial bloom material is gastrointestinal illness, often with severe inflammatory diarrhea (enterocolitis) $[6,12,14,168]$. In the gastrointestinal epithelial layer, which is constantly exposed to a large variety of LPSs, the expression of functional TLR4 is low $[169,170]$. Despite this fact, LPS isolated from cyanobacterial bloom or selected cultured strains is able to activate intestinal epithelial cells in vitro (Šindlerová, unpublished data). Phagocytic immune cells found in the submucosal lamina propria are then activated as well as other immune cells trafficking to the place of inflammation $[167,171$, 172]. These immune cells express TLR4 and can be activated by LPS crossing the mucosal/epithelial barrier due to the increased permeability of inflamed epithelia [167]. In vitro studies show for example that LPS from $M$. aeruginosa blooms and strains activates blood cells, namely human polymorphonuclear leukocytes and monocytes, which are involved in the innate immune defense [157, 158]. Furthermore, rat microglia were shown to be activated by LPS from different cyanobacterial species [173175]. Taken together, these studies indicate that not only intestinal but also immune cells can be affected by cyanobacterial LPS.

Despite the controversy on the inflammatory potential of cyanobacterial LPS, Stewart et al. [156] identified that there is even a lack of evidence to support the gastrointestinal pro-inflammatory reaction of heterotrophic bacterial LPS alone, in the absence of other virulence factors. Considering the pro-inflammatory potential of cyanobacterial bloom extracts, including the bloomassociated heterotrophic bacteria, a cumulative action of several (cyano-) bacterial compounds is very likely [156, $157,164,176,177]$. For example, LPS may contribute to local GIT tissue inflammation and thereby facilitate the access of other toxic compounds, like MCs, to deeper tissues and distribution to other organs and targets of toxicity such as the liver [176].

\section{Other toxins}

Nodularins (NODs) are cyclic non-ribosomal pentapeptide toxins, produced almost exclusively by Nodularia spumigena, that share structural and mechanistic similarities with MCs: non-proteinogenic amino acids like $\mathrm{N}$-methyldehydrobutyrine and D-erythro- $\beta$ methylaspartic acid are incorporated into the peptide ring structure and the ADDA residue mediates toxicity [5 and references therein]. Nodularia spumigena is favored in slightly saline environments; therefore, besides MCs, NOD is a major concern in the Baltic Sea and other brackish habitats $[178,179]$. Few data are available on NOD toxicokinetics, but a similar uptake mechanism (OATP) and mode of action (PP1 and PP2A inhibition) to MCs are proposed and partly supported by experimental evidence in zebrafish and different hepatic cell lines [5, 180, 181]. In addition, NOD has an experimental LD50 of $50-70 \mu \mathrm{g} / \mathrm{kg}$ bw of rodents, which is similar to that of MC-LR $(40-\mu \mathrm{g} / \mathrm{kg}$ bw) $[2,5]$. Therefore, NODs can be expected to cause adverse effects similar to MCs on the GIT. Despite severely inhibiting activity of PPs, NOD in contrast to MCs does not bind covalently to these ubiquitous cytoplasmic enzymes [182].

The cyanobacterial neurotoxins anatoxin-a, anatoxin$\mathrm{a}(\mathrm{S})$, and saxitoxin are fast acting compounds, leading to paralysis and eventually respiratory failure within minutes to few hours $[183,184]$. Due to the rapid onset and specificity of neurological symptoms induced by inhibiting the transfer of excitatory signals, gastrointestinal irritation is unlikely to be a primary effect of these toxins. Nevertheless, exposure to complex cyanobacterial blooms encompasses a mixture of various cyanobacterial, bacterial, and even xenobiotic and anthropogenic compounds. These may modulate the toxic effects of single compounds and result in gastrointestinal symptoms. An 
overview of enterotoxic effects linked to cyanobacterial blooms is given in Table 4.

Except of the well-recognized cyanotoxins, there are many potentially harmful bioactive secondary metabolites poorly characterized. Many of these metabolites, like the non-ribosomal peptides aeruginosins, anabaenopeptins, or cyanopeptolins, have protease inhibiting activities, the latter has been also shown to cause neurotoxic effects and alter pathways linked to DNA damage and repair (Table 4) [185-190].

Another group of poorly characterized cyanobacterial secondary metabolites are cyclic lipopeptides. Representatives of this group are, for example, anabaenolysins and puwainaphycins that cause damage to eukaryotic cell membranes in GIT models and induce necrotic effects (Table 4) [191-193]. More explicit effects on the GIT are reported by Humpage et al. [194]. They described necrotic effects of the novel putative toxin "limnothrixin", isolated from Limnothrix spp., upon oral gavage of an aqueous extract, in liver, kidney, and GIT tissue within 24-h exposure (Table 4). Even though no known toxin was detected in the aqueous extract, there may be the presence of a variety of hydrophilic compound contributing to the effects observed.

The toxicological implications of these activities remain to be elucidated and the characterization of novel putative toxins in an effect-directed screening approach along with the description of structural characteristics should be highly encouraged. Regardless of the unknown toxic potential, these substances may contribute to the severity of gastroenteritis upon cyanobacterial intoxication, for example, by facilitating enteric hemorrhage through interference with the blood coagulation cascade [186].

\section{Co-action of different factors on the GIT}

While single-agent toxic effects are often reported for detoxifying organs like the liver or the kidneys in toxicological studies, the most prominent symptom of harmful algal bloom intoxication is enterocolitis, probably mediated by co-action of multiple virulence factors. Besides the occasionally high abundance of identified cyanobacterial toxins, like MCs, many of the secondary compounds produced by cyanobacteria and eventually released to the water are unidentified or poorly characterized concerning their toxicity (Table 4 ) $[176,195,196]$. Furthermore, bloom-associated bacteria may contribute to the adverse effects observed upon exposure to cyanobacterial blooms, especially gastrointestinal illness [44, 197]. The complex composition of cyanobacterial blooms also leaves space for additive or even synergistic effects of the diverse compounds, which may exacerbate the impact of exposure to otherwise moderately active/toxic compounds.
Also the role of LPS originating from both cyanobacteria and eubacteria has to be critically reflected. The controversies about pro- or anti-inflammatory activities of cyanobacterial LPS may be explained by the effects of bloom-associated bacterial LPS, potentially sensitizing GIT epithelia for the effects of other toxins. A similar effect was observed with the pore-forming lipopeptides anabaenolysins A and B, where a transient increase in cell membrane permeability facilitated nodularin uptake, lowering the effective concentration for nodularin toxicity [191]. Cyanobacterial LPS activity on the mucosal innate immune system does not sufficiently explain the GIT symptoms observed upon acute oral exposure to cyanobacterial blooms. However, the total bloom LPS released during a bloom, including pro-inflammatory LPS from bloom-associated bacteria, may facilitate the penetration of gastrointestinal epithelia and thereby promote the uptake of other cyanobacterial toxins by macrophages or into the blood via the paracellular route as suggested for CYN $[141,156]$.

Considering the described activity of MC-LR as a tumor promoter and the suspicion of CYN carcinogenicity, the mixture of substances with diverse biological activity could finally contribute to colorectal cancer incidents upon long-term exposure to low concentrations, e.g., in drinking water $[21,75,77,198]$.

\section{Summary and future research perspectives}

Cyanobacterial blooms are occurring more frequently and with increasing severity due to global climate change and eutrophication of water bodies, endangering the recreational value of water bodies as well as the safety of drinking water supplies. Hazards linked to cyanobacterial contamination have been recognized and addressed by regulatory authorities (WHO, EFSA, and EPA). For cyanobacterial bloom management, the precautionary principle is proposed, which means that the bloom is considered hazardous until proven safe [185].

Despite gastrointestinal symptoms being the most reported and widespread malaise upon oral exposure to cyanobacterial blooms, research mostly focuses on specific organ toxicity of isolated toxins, i.e., hepatotoxic MCs and CYN. Upon oral exposure, the most relevant route of exposure for humans, the gut epithelium is exposed to the highest toxin concentrations, and it is the first barrier that needs to be overcome for the toxins to reach the blood stream and, subsequently, be distributed to other organs/recipients of toxicity such as the liver. However, gastrointestinal and immunomodulatory effects have not been addressed sufficiently yet, including data allowing for quantitative assessments of doseresponse relationships for acute and chronic adverse outcomes in the GIT in response to individual components of water blooms or their complex mixtures. 


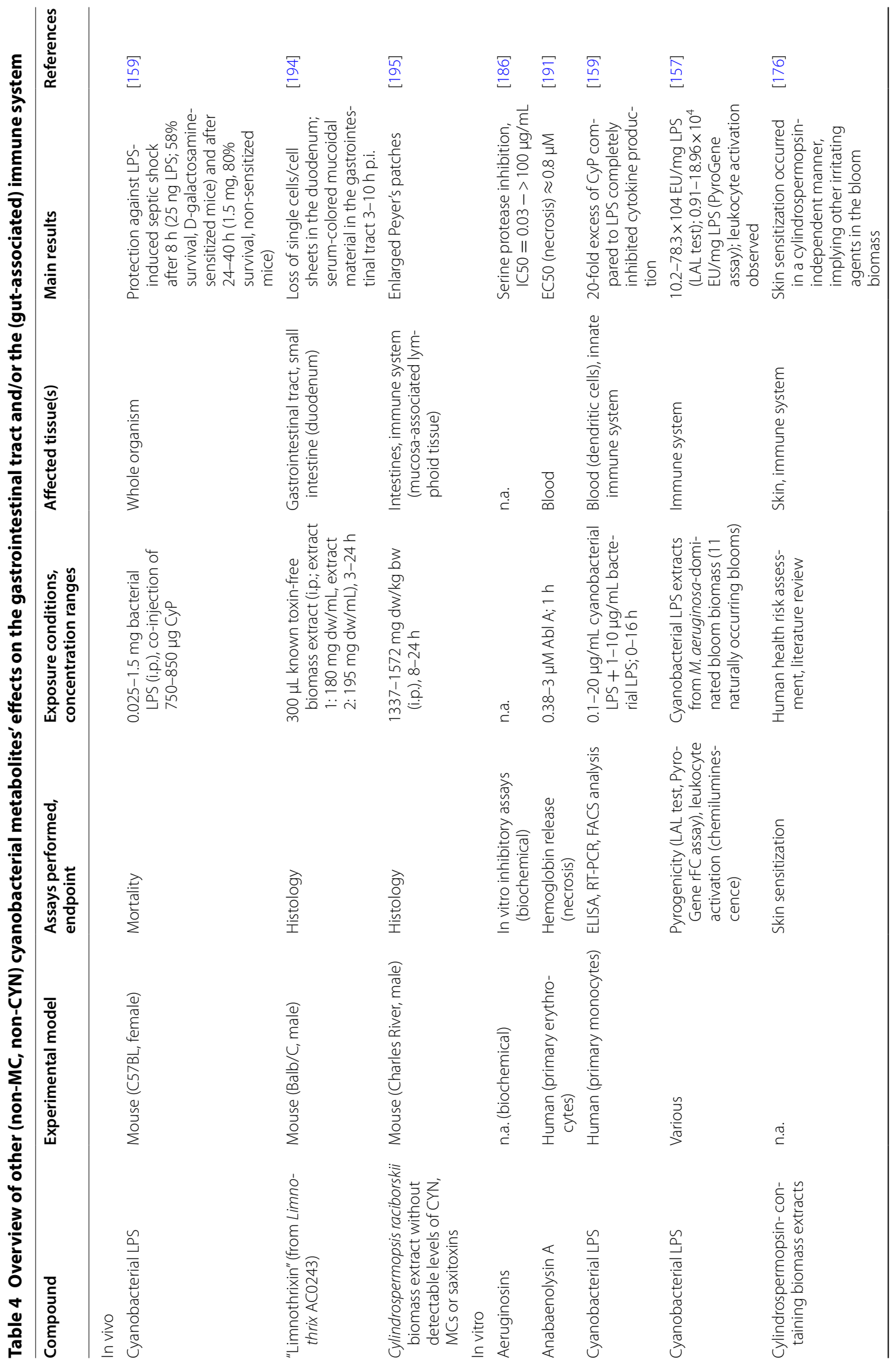




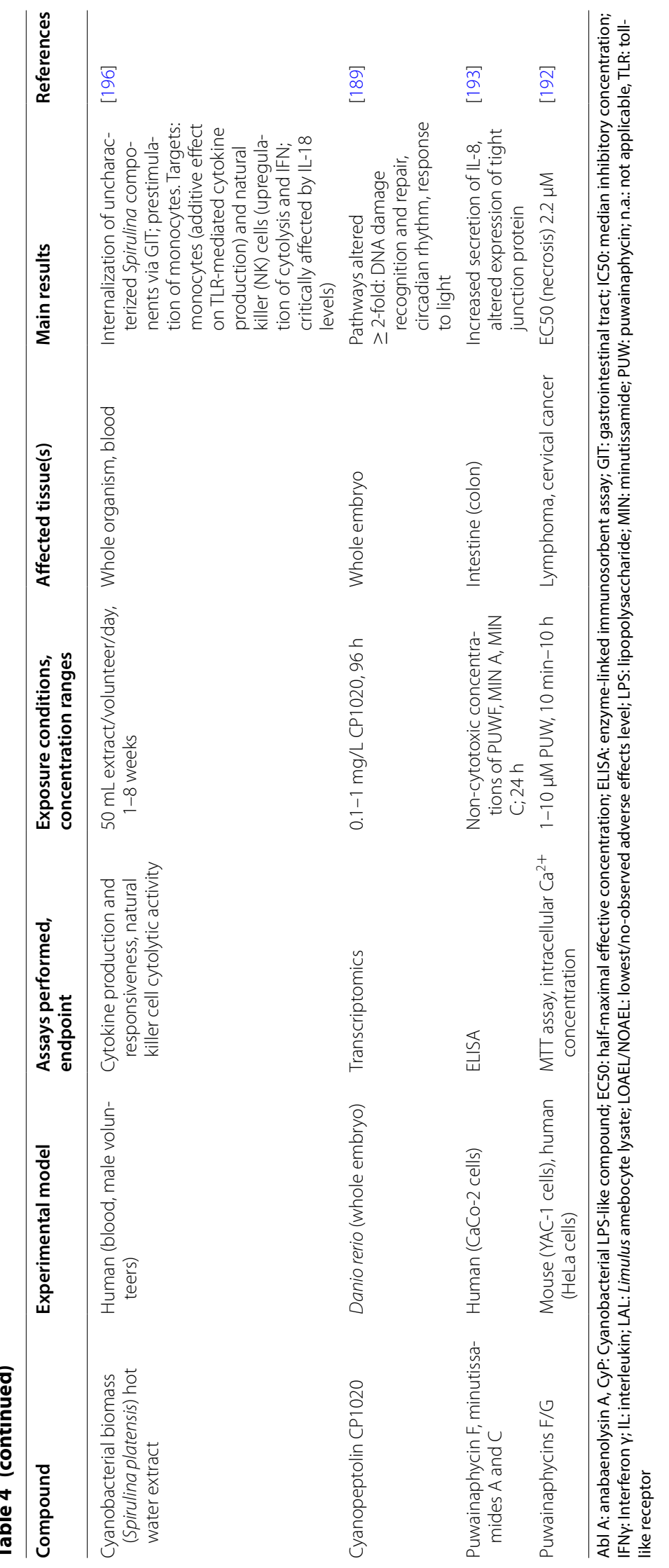


Regarding cyanobacterial effects on the immune system, we need a thorough investigation of mechanistic effects. Currently, effects to the mucosal immune system are predominantly reported as morphologically altered lymphoid follicles and changes in spleen size or weight during in vivo studies, but the underlying mechanisms are not investigated or discussed any further $[120,133]$. The findings summarized in this review need to be elaborated on and verified in a human health relevant system, as most studies are done in fish. Disturbances in the immunological equilibrium including prolonged inflammation may pave the way for other chronic conditions, including carcinogenesis [113].

There is a significant data gap concerning (chronic) oral exposure to cyanobacterial bloom components, which may be covered by epidemiological studies paired with extensive monitoring for cyanobacterial toxin and bloom-associated compounds' abundance in water reservoirs and drinking water supplies. Furthermore, sensitive subpopulations like children and people with chronic gastrointestinal inflammations (e.g., Crohn's disease) are at higher risk which needs to be reflected by risk assessment studies. These groups suffer more often and from more severe enteritis, as their mucosal immune system is still under development or in a permanently inflamed state. In addition, with regard to the carcinogenic and genotoxic potential of MCs and NODs, low-level chronic exposure may contribute to colon carcinoma in later years $[13,113,132,168]$.

\section{Conclusion}

In the naturally occurring complex mixture of cyanobacterial bloom material, multiple factors can contribute to the adverse effect observed on the GIT and the associated mucosal immune system, probably not attributable to a single toxin or agent. Nevertheless, even isolated toxins are reported to adversely affect the small intestine (MC-LR and CYN) or the stomach $(\mathrm{CYN})$, highlighting the importance of further investigation of this relevant system. MC-LR, for which the scarce evidence on GIT irritation is strongest, should even be reconsidered as an enterotoxin. We summarize evidence of inflammatory processes linked to cyanobacterial bloom exposure that may have a significant impact on chronic diseases, such as cancer-especially as some cyanotoxins (MCs) exhibit carcinogenic properties that may be synergistically enhanced by chronic inflammation.

To address the data gaps, we call for more comparable monitoring data to allow statistical (meta-) analyses and conclusive correlation of cyanobacterial blooms and health outcomes for further risk assessment studies.

\section{Materials and methods: description of workflow}

To obtain relevant scientific literature, a systematic review of publications was performed according to the PRISMA scheme (Preferred Reporting Items for Systematic reviews and Meta-Analyses; online Additional file 1: Figure S1). The Scopus database, including PubMed, Web of Knowledge, and Science Direct, was searched for the keywords: (TITLE-ABS-KEY (cyanobacteria OR cyanotoxins OR microcystins OR bloom*) AND TITLE-ABSKEY (epidemiology OR incidence OR health OR health AND effects OR health AND risk OR health AND impact OR health AND hazard OR adverse AND effects OR risk AND assessment OR exposure OR drinking AND water OR intoxication OR disease OR illness) AND TITLEABS-KEY (gastrointestinal OR gastro* OR enteric OR allerg* OR gastric OR inflamm* OR lps OR lipopolysacch $^{*}$ ). No further limits (Access type, publication date, document type etc.) were defined; all results were in English language (last searched on December 13, 2018). 87 articles were identified through the database search; 55 additional articles were identified by other sources. After removing duplicates $(n=16), 126$ articles were screened for eligibility based on the abstracts. Forty-four publications were not eligible on the basis of their abstracts and eighty two underwent further full-text assessment. Of these, 66 articles were included for review purposes.

Titles classified as highly relevant (i.e., review articles and epidemiological studies) indicated further sources, not found by searching the Scopus database.

This review elaborates and expands on five review articles identified as highly relevant [4, 6-9].

\section{Additional file}

Additional file 1: Figure S1. PRISMA 2009 flow diagram.

\begin{abstract}
Abbreviations
Adda: (all-S,all-E)-3-amino-9-methoxy-2,6,8-trimethyl-10-phenyldeca-4,6-dienoic acid; ATX: anatoxin; EC50: half-maximal effective concentration; EFSA: European Food Safety Agency; EPA: Environmental Protection Agency; GIT: gastrointestinal tract; IC50: median inhibitory concentration; IL: interleukin; LD50: half-maximal lethal dose; LOAEL/NOAEL: lowest/no-observed adverse effect level; LOEC/NOEC: lowest/no-observed effect concentration; LPS: lipopolysaccharide; MAPK: mitogen-activated protein kinase; MCs: microcystins; NF-kB: nuclear factor KB; NOD: nodularin; OATP: organic anion transporting polypeptide; PAMP: pathogen-associated molecular pattern; PP1/2A: protein phosphatase 1/2A; PRR: pattern recognition receptor; ROS: reactive oxygen species; STX: saxitoxin; TEER: trans-epithelial electrical resistance; TLR: Toll-like receptor; TNFa: tumor necrosis factor a; WHO: World Health Organization.
\end{abstract}

Acknowledgements

The authors would like to thank the reviewers for their thorough feedback, constructive comments, and rapid reply. 


\section{Authors' contributions}

Conceptualization: $\mathrm{KH}, \mathrm{PB}, \mathrm{LS}$, and $\mathrm{BK}$; methodology: BK; writing-original draft preparation, BK; writing - review and editing: $\mathrm{KH}, \mathrm{PB}, \mathrm{LS}$ and $\mathrm{BK}$; supervision: $\mathrm{KH}$ and $\mathrm{PB}$; project administration: $\mathrm{KH}$ and $\mathrm{LS}$; funding acquisition: $\mathrm{KH}$ and LŠ. All authors read and approved the final manuscript.

\section{Funding}

The research has received funding from the European Union's Horizon 2020 research and innovation program under the Marie Skłodowska-Curie Grant Agreement No. 722493 NaToxAq (BK), the Czech Science Foundation Grant No. 16-24949S, and by the RECETOX Research Infrastructure (LM2015051 and CZ.02.1.01/0.0/0.0/16_013/0001761). Any opinions in this article reflect only the author's view and the European Union's Research Executive Agency is not responsible for any use that may be made of the information it contains.

\section{Availability of data and materials}

Not applicable.

Ethics approval and consent to participate

Not applicable.

\section{Consent for publication}

Not applicable.

\section{Competing interests}

The authors declare that they have no competing interests.

\section{Author details}

1 RECETOX, Faculty of Science, Masaryk University, Kamenice 753/5, 625 00 Brno, Czech Republic. ${ }^{2}$ Department of Experimental Phycology and Ecotoxicology, Institute of Botany, Czech Academy of Sciences, Lidická 25/27, 60100 Brno, Czech Republic. ${ }^{3}$ Department of Biophysics of Immune System, Institute of Biophysics, Czech Academy of Sciences, Královopolská 135, 612 65 Brno, Czech Republic

Received: 1 February 2019 Accepted: 4 May 2019

Published online: 21 May 2019

\section{References}

1. Codd BG, Azevedo S, Bagchi S, et al (2005) International Hydrological Programme CYANONET - a global network for cyanobacterial bloom and toxin risk management initial situation assessment and recommendations IHP-VI technical document in hydrology Nº76 UNESCO working series SC-2005/WS/55

2. Chorus I, Bartram J (1999) Toxic cyanobacteria in water: a guide to their public health consequences, monitoring, and management. E \& FN Spon, New York

3. Huisman J, Codd GA, Paerl HW et al (2018) Cyanobacterial blooms. Nat Rev Microbiol 16:471-483. https://doi.org/10.1038/s41579-018-0040-1

4. Verspagen JMH, Van de Waal DB, Finke JF et al (2014) Rising $\mathrm{CO}_{2}$ levels will intensify phytoplankton blooms in eutrophic and hypertrophic lakes. PLoS ONE 9:e104325. https://doi.org/10.1371/journal.pone.01043 25

5. Buratti FM, Manganelli M, Vichi S et al (2017) Cyanotoxins: producing organisms, occurrence, toxicity, mechanism of action and human health toxicological risk evaluation. Arch Toxicol 91:1049-1130. https:// doi.org/10.1007/s00204-016-1913-6

6. Wood R (2016) Acute animal and human poisonings from cyanotoxin exposure-a review of the literature. Environ Int 91:276-282. https:// doi.org/10.1016/j.envint.2016.02.026

7. Stewart I, Seawright AA, Shaw GR (2008) Cyanobacterial poisoning in livestock, wild mammals and birds-an overview. Cyanobacterial harmful algal blooms: state of the science and research needs. Springer New York, New York, pp 613-637

8. Azevedo SMF, Carmichael WW, Jochimsen EM et al (2002) Human intoxication by microcystins during renal dialysis treatment in Caruaru—Brazil. Toxicology 181:441-446. https://doi.org/10.1016/ S0300-483X(02)00491-2
9. Turner PC Gammie AJ, Hollinrake K, Codd GA (1990) Pneumonia associated with cyanobacteria. BMJ 300:1440. https://doi.org/10.1136/ bmj.300.6737.1440

10. Giannuzzi L, Sedan D, Echenique R, Andrinolo D (2011) An acute case of intoxication with cyanobacteria and cyanotoxins in recreational water in Salto Grande Dam, Argentina. Mar Drugs 9:2164-2175

11. Vidal F, Sedan D, D'Agostino D et al (2017) Recreational exposure during algal bloom in Carrasco Beach, Uruguay: a liver failure case report. Toxins (Basel) 9:E267. https://doi.org/10.3390/toxins9090267

12. Svirčev Z, Drobac D, Tokodi N et al (2017) Toxicology of microcystins with reference to cases of human intoxications and epidemiological investigations of exposures to cyanobacteria and cyanotoxins. Arch Toxicol 91:621-650. https://doi.org/10.1007/s00204-016-1921-6

13. Falconer IR (1999) An Overview of problems caused by toxic bluegreen algae (cyanobacteria) in drinking and recreational water. Environ Toxicol 14:5-12. https://doi.org/10.1002/(SICI)1522-7278(19990 2) 14:1\%3c5:AID-TOX3\%3e3.0.CO;2-0

14. Lévesque B, Gervais M-C, Chevalier P et al (2014) Prospective study of acute health effects in relation to exposure to cyanobacteria. Sci Total Environ 466-467:397-403

15. Lévesque B, Gervais M-C, Chevalier P et al (2016) Exposure to cyanobacteria: acute health effects associated with endotoxins. Public Health 134:98-101. https://doi.org/10.1016/J.PUHE.2015.11.027

16. Bourke ATC, Hawes RB, Neilson A, Stallman ND (1983) An outbreak of hepato-enteritis (the Palm Island mystery disease) possibly caused by algal intoxication. Toxicon 21:45-48. https://doi.org/10.1016/00410101(83)90151-4

17. Falconer IR, Beresford AM, Runnegar MT (1983) Evidence of liver damage by toxin from a bloom of the blue-green alga, Microcystis aeruginosa. Med J Aust 1:511-514

18. Zheng C, Zeng H, Lin H et al (2017) Serum microcystin levels positively linked with risk of hepatocellular carcinoma: a case-control study in southwest China. Hepatology 66:1519-1528. https://doi.org/10.1002/ hep.29310

19. Liu W, Wang L, Zheng $C$ et al (2018) Microcystin-LR increases genotoxicity induced by aflatoxin B1 through oxidative stress and DNA base excision repair genes in human hepatic cell lines. Environ Pollut 233:455-463. https://doi.org/10.1016/j.envpol.2017.10.067

20. He L, Huang Y, Guo Q et al (2018) Chronic microcystin-LR exposure induces hepatocarcinogenesis via increased gankyrin in vitro and in vivo. Cell Physiol Biochem 49:1420-1430. https://doi. org/10.1159/000493446

21. Zhou L, Yu H, Chen K (2002) Relationship between microcystin in drinking water and colorectal cancer. Biomed Environ Sci 15:166-171

22. Campos Da Cunha-Bellém FN (2014) As cianobactérias na água e a morbilidade e mortalidade na região do Alentejo. Universidade de Évora

23. Svirčev Z, Drobac D, Tokodi N et al (2014) Epidemiology of cancers in Serbia and possible connection with cyanobacterial blooms. J Environ Sci Heal Part C 32:319-337. https://doi.org/10.1080/10590 501.2014.967053

24. Xu M, Yang J, Lin Y et al (2003) Microcystins in drinking water and mortality of major cancer in a city along Taihu Lake. Chin J Prev Control Chronic Non Commun Dis 11:112-113

25. Fleming LE, Rivero C, Burns J et al (2002) Blue green algal (cyanobacterial) toxins, surface drinking water, and liver cancer in Florida. Harmful Algae 1:157-168. https://doi.org/10.1016/S1568-9883(02)00026-4

26. Tisdale ES (1931) Epidemic of intestinal disorders in Charleston, W. Va. occurring simultaneously with unprecedented water supply conditions. Am J Public Heal 21:198-200

27. Zilberg B (1966) Gastroenteritis in Salisbury. European children - a fiveyear study. Cent Afr J Med 12:164-168

28. Keleti G, Sykora JL, Lippy EC, Shapiro MA (1979) Composition and biological properties of lipopolysaccharides isolated from Schizothrix calcicola (Ag.) Gomont (Cyanobacteria). Appl Environ Microbiol 38:471-477

29. Lippy EC, Erb J (1976) Gastrointestinal illness at Sewickley, Pa. J Am Water Works Assoc 68:606-610. https://doi. org/10.1002/j.1551-8833.1976.tb02504.x

30. Byth S (1980) Palm Island mystery disease. Med J Aust 2:40-42 
31. Teixeira G, Costa C, de Carvalho VL et al (1993) Gastroenteritis epidemic in the area of the Itaparica Dam, Bahia, Brazil. Bull Pan Am Health Organ 27:244-253

32. Anadotter H, Cronberg G, Lawton L et al (2001) An extensive outbreak of gastroenteritis associated with the toxic cyanobacterium Planktothrix agardhii (Oscillatoriales, Cyanophyceae) in Scania, South Sweden. In: Chorus I (ed) Cyanotoxins, occurrence, causes, consequences. Springer, Berlin, pp 200-208

33. El Saadi O, Esterman AJ, Cameron S, Roder DM (1995) Murray river water, raised cyanobacterial cell counts, and gastrointestinal and dermatological symptoms. Med J Aust 162:122-125

34. Gunnarsson H, Sanseovic A-M (2001) Possible linkages between algae toxins in drinking water and related illnesses in Windhoek Namibia. Bacherlor's degree project, Kristianstad University College, School of Engineering

35. Svirčev Z, Drobac D, Tokodi N et al (2017) Lessons from the Užice case. Handbook of cyanobacterial monitoring and cyanotoxin analysis. John Wiley \& Sons Ltd, Chichester, pp 298-308

36. McCarty CL, Nelson L, Eitniear S et al (2016) Community needs assessment after microcystin toxin contamination of a municipal water supply_Lucas County, Ohio, September 2014. Morb Mortal Wkly Rep 65:925-929. https://doi.org/10.15585/mmwr.mm6535a1

37. Soward TE (2011) Evaluation of cancer from exposure to cyanotoxins in drinking water at Grand Lake Saint Marys. Wright State University, Dayton

38. Dillenberg HO, Dehnel MK (1960) Toxic waterbloom in Saskatchewan, 1959. Can Med Assoc J 83:1151-1154

39. Billings WH (1981) Water-associated human illness in Northeast Pennsylvania and its suspected association with blue-green algae blooms. In: Carmichael WW (ed) The water environment. Springer, Boston, pp 243-255

40. Pilotto LS, Douglas RM, Burch MD et al (1997) Health effects of exposure to cyanobacteria (blue-green algae) during recreational water-related activities. Aust N Z J Public Health 21:562-566

41. Stewart I, Webb PM, Schluter PJ et al (2006) Epidemiology of recreational exposure to freshwater cyanobacteria - an international prospective cohort study. BMC Public Health 6:93

42. Codd G, Bell S, Kaya K et al (1999) Cyanobacterial toxins, exposure routes and human health. Eur J Phycol 34:405-415. https://doi. org/10.1080/09670269910001736462

43. Rapala J, Robertson A, Negri AP et al (2005) First report of saxitoxin in Finnish lakes and possible associated effects on human health. Environ Toxicol 20:331-340. https://doi.org/10.1002/tox.20109

44. Berg KA, Lyra C, Niemi RM et al (2011) Virulence genes of Aeromonas isolates, bacterial endotoxins and cyanobacterial toxins from recreational water samples associated with human health symptoms. J Water Health 9:670. https://doi.org/10.2166/wh.2011.206

45. Hilborn ED, Roberts VA, Backer L et al (2014) Algal bloom-associated disease outbreaks among users of freshwater lakes-United States, 2009-2010. Morb Mortal Wkly Rep 63:11-15

46. Trevino-Garrison I, DeMent J, Ahmed F et al (2015) Human illnesses and animal deaths associated with freshwater harmful algal blooms-Kansas. Toxins (Basel) 7:353-366. https://doi.org/10.3390/ toxins 7020353

47. WHO (2003) Cyanobacterial toxins: Microcystin-LR in drinking-water background document for development of WHO guidelines for drinking-water quality. Guidel Drink Qual 2nd ed Add to Vol 2 Heal criteria other Support Inf

48. Adamovsky O, Buerger AN, Wormington AM et al (2018) The gut microbiome and aquatic toxicology: an emerging concept for environmental health. Environ Toxicol Chem 37:2758-2775. https://doi.org/10.1002/ etc. 4249

49. Lin J, Chen J, He J et al (2015) Effects of microcystin-LR on bacterial and fungal functional genes profile in rat gut. Toxicon 96:50-56. https://doi. org/10.1016/j.toxicon.2015.01.011

50. Chen J, Xie P, Lin J et al (2015) Effects of microcystin-LR on gut microflora in different gut regions of mice. J Toxicol Sci 40:485-494. https:// doi.org/10.2131/jts.40.485

51. Mowat AM, Agace WW (2014) Regional specialization within the intestinal immune system. Nat Rev Immunol 14:667-685. https://doi. org/10.1038/nri3738
52. Agace WW, McCoy KD (2017) Regionalized development and maintenance of the intestinal adaptive immune landscape. Immunity 46:532-548. https://doi.org/10.1016/J.IMMUNI.2017.04.004

53. Ziegler SF, Buckner JH (2009) FOXP3 and the regulation of Treg/Th17 differentiation. Microbes Infect 11:594-598. https://doi.org/10.1016/J. MICINF.2009.04.002

54. Rakoff-Nahoum S, Paglino J, Eslami-Varzaneh F et al (2004) Recognition of commensal microflora by Toll-Like receptors is required for intestinal homeostasis. Cell 118:229-241. https://doi.org/10.1016/J. CELL.2004.07.002

55. Murphy K, Weaver C (2016) Janeway's immunobiology, 9th edn. Garland Science, New York

56. Testai E, Buratti FM, Funari E et al (2016) Review and analysis of occurrence, exposure and toxicity of cyanobacteria toxins in food. EFSA Support Publ. https://doi.org/10.2903/SP.EFSA.2016.EN-998

57. Spoof L, Catherine A (2017) Appendix 3: tables of microcystins and nodularins. Handbook of cyanobacterial monitoring and cyanotoxin analysis. John Wiley \& Sons Ltd, Chichester, pp 526-537

58. Hilborn ED, Carmichael WW, Soares RM et al (2007) Serologic evaluation of human microcystin exposure. Environ Toxicol 22:459-463. https:// doi.org/10.1002/tox.20281

59. Greer B, Meneely JP, Elliott CT (2018) Uptake and accumulation of microcystin-LR based on exposure through drinking water: an animal model assessing the human health risk. Sci Rep 8:4913. https://doi. org/10.1038/s41598-018-23312-7

60. Chen J, Xie P, Li L, Xu J (2009) First identification of the hepatotoxic microcystins in the serum of a chronically exposed human population together with indication of hepatocellular damage. Toxicol Sci 108:81-89. https://doi.org/10.1093/toxsci/kfp009

61. Mohamed ZA, Bakr A, Soliman HA (2018) Bioavailability of bound microcystins in mice orally fed with contaminated tilapia edible tissues: implications to human health. Toxicon 151:34-36. https://doi. org/10.1016/j.toxicon.2018.06.082

62. Fischer A, Hoeger SJ, Stemmer K et al (2010) The role of organic anion transporting polypeptides (OATPS/SLCOs) in the toxicity of different microcystin congeners in vitro: a comparison of primary human hepatocytes and OATP-transfected HEK293 cells. Toxicol Appl Pharmacol 245:9-20. https://doi.org/10.1016/j.taap.2010.02.006

63. Fischer WJ, Altheimer S, Cattori V et al (2005) Organic anion transporting polypeptides expressed in liver and brain mediate uptake of microcystin. Toxicol Appl Pharmacol 203:257-263. https://doi.org/10.1016/j. taap.2004.08.012

64. Oswald S (2019) Organic anion transporting polypeptide (OATP) transporter expression, localization and function in the human intestine. Pharmacol Ther 195:39-53. https://doi.org/10.1016/J.PHARMTHERA .2018.10.007

65. Drozdzik M, Gröer C, Penski J et al (2014) Protein abundance of clinically relevant multidrug transporters along the entire length of the human intestine. Mol Pharm 11:3547-3555. https://doi.org/10.1021/mp500 $330 y$

66. Miyauchi E, Tachikawa M, Declèves X et al (2016) Quantitative atlas of cytochrome P450, UDP-glucuronosyltransferase, and transporter proteins in jejunum of morbidly obese subjects. Mol Pharm 13:2631-2640. https://doi.org/10.1021/acs.molpharmaceut.6b00085

67. Vaessen SFC, van Lipzig MMH, Pieters RHH et al (2017) Regional expression levels of drug transporters and metabolizing enzymes along the pig and human intestinal tract and comparison with Caco-2 cells. Drug Metab Dispos 45:353-360. https://doi.org/10.1124/dmd.116.072231

68. Moreau A, Le Vee M, Jouan E et al (2011) Drug transporter expression in human macrophages. Fundam Clin Pharmacol 25:743-752. https://doi. org/10.1111/j.1472-8206.2010.00913.x

69. Adamovsky O, Moosova Z, Pekarova M et al (2015) Immunomodulatory potency of microcystin, an important water-polluting cyanobacterial toxin. Environ Sci Technol 49:12457-12464. https://doi.org/10.1021/acs. est.5b02049

70. Moosova Z, Hrouzek P, Kapuscik A et al (2018) Immunomodulatory effects of selected cyanobacterial peptides in vitro. Toxicon 149:20-25

71. Shimada H, Nakamura Y, Nakanishi T, Tamai I (2015) OATP2A1/SLCO2A1mediated prostaglandin E2 loading into intracellular acidic compartments of macrophages contributes to exocytotic secretion. Biochem Pharmacol 98:629-638. https://doi.org/10.1016/j.bcp.2015.10.009 
72. Nakano T, Katsuki S, Chen M et al (2019) Uremic toxin indoxyl sulfate promotes proinflammatory macrophage activation via the interplay of OATP2B1 and DII4-Notch signaling. Circulation 139:78-96. https://doi. org/10.1161/CIRCULATIONAHA.118.034588

73. Campos A, Vasconcelos V (2010) Molecular mechanisms of microcystin toxicity in animal cells. Int J Mol Sci 11:268-287. https://doi. org/10.3390/ijms11010268

74. Mumby M (2007) PP2A: unveiling a reluctant tumor suppressor. Cell 130:21-24. https://doi.org/10.1016/j.cell.2007.06.034

75. Ren Y, Yang M, Chen M et al (2017) Microcystin-LR promotes epithelialmesenchymal transition in colorectal cancer cells through PI3-K/AKT and SMAD2. Toxicol Lett 265:53-60. https://doi.org/10.1016/j.toxle t.2016.11.004

76. Ito E, Kondo F, Terao K, Harada K-I (1997) Neoplastic nodular formation in mouse liver induced by repeated intraperitoneal injections of microcystin-LR. Toxicon 35:1453-1457

77. Zhu Y, Zhong X, Zheng S et al (2005) Transformation of immortalized colorectal crypt cells by microcystin involving constitutive activation of Akt and MAPK cascade. Carcinogenesis 26:1207-1214. https://doi. org/10.1093/carcin/bgi069

78. Fawell JK, Mitchell RE, Everett DJ, Hill RE (1999) The toxicity of cyanobacterial toxins in the mouse: I Microcystin-LR. Hum Exp Toxicol 18:162-167. https://doi.org/10.1177/096032719901800305

79. Niedermeyer $T$ (2014) Microcystin congeners described in the literature. https://doi.org/10.6084/m9.figshare.880756.v5

80. Meriluoto J, Spoof L, Codd GA (2016) Handbook of cyanobacterial monitoring and cyanotoxin analysis. Wiley, Chichester

81. Bain P, Shaw G, Patel B (2007) Induction of p53-regulated gene expression in human cell lines exposed to the cyanobacterial toxin cylindrospermopsin. J Toxicol Environ Health Part A 70:1687-1693. https://doi. org/10.1080/15287390701434877

82. Shaw G, Lam PKS (2007) Health aspects of freshwater cyanobacterial toxins. Water Sci Technol Water Supply 7:193. https://doi.org/10.2166/ ws.2007.054

83. Garibo D, Flores C, Cetó X et al (2014) Inhibition equivalency factors for microcystin variants in recombinant and wild-type protein phosphatase 1 and 2A assays. Environ Sci Pollut Res 21:10652-10660. https ://doi.org/10.1007/s11356-014-3065-7

84. Chen Y-M, Lee T-H, Lee S-J et al (2006) Comparison of protein phosphatase inhibition activities and mouse toxicities of microcystins. Toxicon 47:742-746. https://doi.org/10.1016/j.toxicon.2006.01.026

85. Zong W, Wang X, Du Y et al (2017) Molecular mechanism for the regulation of microcystin toxicity to protein phosphatase 1 by glutathione conjugation pathway. Biomed Res Int 2017:1-10. https://doi. org/10.1155/2017/9676504

86. Dietrich D, Hoeger S (2005) Guidance values for microcystins in water and cyanobacterial supplement products (blue-green algal supplements): a reasonable or misguided approach? Toxicol Appl Pharmacol 203:273-289

87. Zurawell RW, Chen H, Burke JM, Prepas EE (2005) Hepatotoxic cyanobacteria: a review of the biological importance of microcystins in freshwater environments. J Toxicol Environ Health Part B 8:1-37. https:// doi.org/10.1080/10937400590889412

88. Feurstein D, Holst K, Fischer A, Dietrich DR (2009) OATP-associated uptake and toxicity of microcystins in primary murine whole brain cells. Toxicol Appl Pharmacol 234:247-255. https://doi.org/10.1016/j. taap.2008.10.011

89. Ito E, Kondo F, Harada K-I (2000) First report on the distribution of orally administered microcystin- LR in mouse tissue using an immunostaining method. Toxicon 38:37-48. https://doi.org/10.1016/S0041 -0101(99)00084-7

90. McLellan NL, Manderville RA (2017) Toxic mechanisms of microcystins in mammals. Toxicol Res (Camb) 6:391-405. https://doi.org/10.1039/ C7TX00043J

91. Vesterkvist P, Misiorek J, Spoof L et al (2012) Comparative cellular toxicity of hydrophilic and hydrophobic microcystins on Caco-2 Cells. Toxins (Basel) 4:1008-1023. https://doi.org/10.3390/toxins4111008

92. Gaudin J, Huet S, Jarry G, Fessard V (2008) In vivo DNA damage induced by the cyanotoxin microcystin-LR: comparison of intraperitoneal and oral administrations by use of the comet assay. Mutat
Res Toxicol Environ Mutagen 652:65-71. https://doi.org/10.1016/j. mrgentox.2007.10.024

93. Botha N, van de Venter M, Downing TG et al (2004) The effect of intraperitoneally administered microcystin-LR on the gastrointestinal tract of Balb/c mice. Toxicon 43:251-254. https://doi.org/10.1016/j. toxicon.2003.11.026

94. Falconer IR (1996) Potential impact on human health of toxic cyanobacteria. Phycologia 35:6-11

95. Sedan D, Laguens M, Copparoni G et al (2015) Hepatic and intestine alterations in mice after prolonged exposure to low oral doses of microcystin-LR. Toxicon 104:26-33

96. Moreno IM, Mate A, Repetto G et al (2003) Influence of microcystinLR on the activity of membrane enzymes in rat intestinal mucosa. J Physiol Biochem 59:293-299

97. Puerto M, Pichardo S, Jos Á, Cameán AM (2010) Microcystin-LR induces toxic effects in differentiated and undifferentiated Caco-2 cells. Arch Toxicol 84:405-410. https://doi.org/10.1007/s0020 4-010-0513-0

98. Žegura B, Volčič M, Lah TT, Filipič M (2008) Different sensitivities of human colon adenocarcinoma (CaCo-2), astrocytoma (IPDDC-A2) and lymphoblastoid (NCNC) cell lines to microcystin-LR induced reactive oxygen species and DNA damage. Toxicon 52:518-525. https ://doi.org/10.1016/J.TOXICON.2008.06.026

99. Fernández DA, Louzao MC, Vilariño N et al (2014) Evaluation of the intestinal permeability and cytotoxic effects of cylindrospermopsin. Toxicon 91:23-34. https://doi.org/10.1016/j.toxicon.2014.08.072

100. Henri J, Huguet A, Delmas J-M et al (2014) Low in vitro permeability of the cyanotoxin microcystin-LR across a Caco-2 monolayer: with identification of the limiting factors using modelling. Toxicon 91:5-14. https://doi.org/10.1016/j.toxicon.2014.07.023

101. Huguet A, Henri J, Petitpas M et al (2013) Comparative cytotoxicity, oxidative stress, and cytokine secretion induced by two cyanotoxin variants, microcystin-LR and -RR, in human intestinal Caco-2 cells. J Biochem Mol Toxicol 27:253-258. https://doi.org/10.1002/jbt.21482

102. Zeller P, Quenault H, Huguet A et al (2012) Transcriptomic comparison of cyanotoxin variants in a human intestinal model revealed major differences in oxidative stress response: effects of MC-RR and MC-LR on Caco-2 cells. Ecotoxicol Environ Saf 82:13-21

103. Zeller P, Clément M, Fessard V (2011) Similar uptake profiles of microcystin-LR and -RR in an in vitro human intestinal model. Toxicology 290:7-13

104. Miao C, Ren Y, Chen M et al (2016) Microcystin-LR promotes migration and invasion of colorectal cancer through matrix metalloproteinase-13 up-regulation. Mol Carcinog 55:514-524. https://doi. org/10.1002/mc.22298

105. Zhu Q, Wang Z, Zhou L et al (2017) The role of cadherin-11 in microcystin-LR-induced migration and invasion in colorectal carcinoma cells. Oncol Lett 15:1417-1422. https://doi.org/10.3892/ol.2017.7458

106. Ren Y, Yang M, Ma R et al (2019) Microcystin-LR promotes migration via the cooperation between microRNA-221/PTEN and STAT3 signal pathway in colon cancer cell line DLD-1. Ecotoxicol Environ Saf 167:107-113. https://doi.org/10.1016/j.ecoenv.2018.09.065

107. Lone Y, Bhide M, Koiri RK (2016) Microcystin-LR induced immunotoxicity in mammals. J Toxicol 2016:1-5. https://doi. org/10.1155/2016/8048125

108. Djediat C, Malécot M, de Luze A et al (2010) Localization of microcystinLR in medaka fish tissues after cyanotoxin gavage. Toxicon 55:531-535. https://doi.org/10.1016/J.TOXICON.2009.10.005

109. Sieroslawska A, Rymuszka A, Adaszek $Ł$ (2015) Effects of cylindrospermopsin on the phagocytic cells of the common carp (Cyprinus carpio L.). J Appl Toxicol 35:1406-1414. https://doi.org/10.1002/jat.3118

110. Best J, Pflugmacher S, Wiegand C et al (2002) Effects of enteric bacterial and cyanobacterial lipopolysaccharides, and of microcystin-LR, on glutathione S-transferase activities in zebra fish (Danio rerio). Aquat Toxicol 60:223-231. https://doi.org/10.1016/S0166-445X(02)00010-3

111. Sierosławska A, Rymuszka A, Bownik A, Skowroński T (2007) The influence of microcystin-LR on fish phagocytic cells. Hum Exp Toxicol 26:603-607. https://doi.org/10.1177/09603271060080075

112. Chen T, Shen P, Zhang J, Hua Z (2005) Effects of microcystin-LR on patterns of iNOS and cytokine mRNA expression in macrophagesin vitro. Environ Toxicol 20:85-91. https://doi.org/10.1002/tox.20081 
113. Ullman TA, Itzkowitz SH (2011) Intestinal inflammation and cancer. Gastroenterology 140:1807-1816.e1. https://doi.org/10.1053/j.gastr 0.2011 .01 .057

114. Falconer IR (2005) Is there a human health hazard from microcystins in the drinking water supply? Acta Hydrochim Hydrobiol 33:64-71. https ://doi.org/10.1002/aheh.200300551

115. Nishiwaki R, Ohta T, Sueoka E et al (1994) Two significant aspects of microcystin-LR: specific binding and liver specificity. Cancer Lett 83:283-289. https://doi.org/10.1016/0304-3835(94)90331-X

116. Wang Q, Xie P, Chen J, Liang G (2008) Distribution of microcystins in various organs (heart, liver, intestine, gonad, brain, kidney and lung) of Wistar rat via intravenous injection. Toxicon 52:721-727. https://doi. org/10.1016/J.TOXICON.2008.08.004

117. Puerto M, Pichardo S, Jos Á, Cameán AM (2009) Comparison of the toxicity induced by microcystin-RR and microcystin-YR in differentiated and undifferentiated Caco-2 cells. Toxicon 54:161-169. https://doi. org/10.1016/J.TOXICON.2009.03.030

118. Zhou Y, Xu X, Yu B, Yu G (2017) Characterization of in vitro effects of microcystin-LR on intestinal epithelial cells. Environ Toxicol 32:1539_ 1547. https://doi.org/10.1002/tox.22375

119. Ohtani I, Moore RE, Runnegar MTC (1992) Cylindrospermopsin: a potent hepatotoxin from the blue-green alga Cylindrospermopsis raciborskii. J Am Chem Soc 114:7941-7942. https://doi.org/10.1021/ja00046a067

120. Pichardo S, Cameán AM, Jos A (2017) In vitro toxicological assessment of cylindrospermopsin: a review. Toxins (Basel) 9:402. https://doi. org/10.3390/toxins9120402

121. Froscio SM, Humpage AR, Burcham PC, Falconer IR (2003) Cylindrospermopsin-induced protein synthesis inhibition and its dissociation from acute toxicity in mouse hepatocytes. Environ Toxicol 18:243-251. https ://doi.org/10.1002/tox.10121

122. Norris RLG, Seawright AA, Shaw GR et al (2002) Hepatic xenobiotic metabolism of cylindrospermopsin in vivo in the mouse. Toxicon 40:471-476

123. Runnegar MT, Kong S, Zhong Y-Z, Lu SC (1995) Inhibition of reduced glutathione synthesis by cyanobacterial alkaloid cylindrospermopsin in cultured rat hepatocytes. Biochem Pharmacol 49:219-225

124. Runnegar MTC, Kong SM, Zhong YZ et al (1994) The role of glutathione in the toxicity of a novel cyanobacterial alkaloid cylindrospermopsin in cultured rat hepatocytes. Biochem Biophys Res Commun 201:235-241. https://doi.org/10.1006/bbrc.1994.1694

125. Humpage AR, Fontaine F, Froscio S et al (2005) Cylindrospermopsin genotoxicity and cytotoxicity: role of cytochrome P-450 and oxidative stress. J Toxicol Environ Health Part A 68:739-753. https://doi. org/10.1080/15287390590925465

126. Bazin E, Mourot A, Humpage AR, Fessard V (2010) Genotoxicity of a freshwater cyanotoxin, cylindrospermopsin, in two human cell lines: Caco-2 and HepaRG. Environ Mol Mutagen 51:251-259

127. Kittler K, Hurtaud-Pessel D, Maul R et al (2016) In vitro metabolism of the cyanotoxin cylindrospermopsin in HepaRG cells and liver tissue fractions. Toxicon 110:47-50. https://doi.org/10.1016/j.toxic on.2015.11.007

128. Liebel S, de Oliveira Ribeiro CA, de Magalhães VF et al (2015) Low concentrations of cylindrospermopsin induce increases of reactive oxygen species levels, metabolism and proliferation in human hepatoma cells (HepG2). Toxicol In Vitro 29:479-488. https://doi.org/10.1016/j. tiv.2014.12.022

129. Fessard V, Bernard C (2003) Cell alterations but no DNA strand breaks induced in vitro by cylindrospermopsin in $\mathrm{CHO}$ K1 cells. Environ Toxicol 18:353-359. https://doi.org/10.1002/tox.10136

130. Lankoff A, Wojcik A, Lisowska $\mathrm{H}$ et al (2007) No induction of structural chromosomal aberrations in cylindrospermopsin-treated $\mathrm{CHO}-\mathrm{K} 1$ cells without and with metabolic activation. Toxicon 50:1105-1115. https:// doi.org/10.1016/j.toxicon.2007.07.021

131. Humpage AR, Falconer IR (2003) Oral toxicity of the cyanobacterial toxin cylindrospermopsin in male Swiss albino mice: determination of no observed adverse effect level for deriving a drinking water guideline value. Environ Toxicol 18:94-103. https://doi.org/10.1002/tox.10104

132. Falconer IR, Humpage AR (2006) Cyanobacterial (blue-green algal) toxins in water supplies: cylindrospermopsins. Environ Toxicol 21:299-304. https://doi.org/10.1002/tox.20194
133. Seawright AA, Nolan CC, Shaw GR et al (1999) The oral toxicity for mice of the tropical cyanobacterium Cylindrospermopsis raciborskii (Woloszynska). Environ Toxicol 14:135-142. https://doi.org/10.1002/ (SICI)1522-7278(199902)14:1\%3c135:AID-TOX17\%3e3.0.CO;2-L

134. Marchev AS, Dimitrova PA, Burns AJ et al (2017) Oxidative stress and chronic inflammation in osteoarthritis: can NRF2 counteract these partners in crime? Ann N Y Acad Sci 1401:114-135. https://doi.org/10.1111/ nyas. 13407

135. Vasicek O, Lojek $A$, Jancinova $V$ et al (2014) Role of histamine receptors in the effects of histamine on the production of reactive oxygen species by whole blood phagocytes. Life Sci 100:67-72. https://doi. org/10.1016/J.LFS.2014.01.082

136. Aderem A (2003) Phagocytosis and the inflammatory response. J Infect Dis 187:S340-S345. https://doi.org/10.1086/374747

137. Moosova Z, Pekarova M, Svihalkova Sindlerova L et al (2019) Immunomodulatory effects of cyanobacterial toxin cylindrospermopsin on innate immune cells. Chemosphere 226:439-446. https://doi. org/10.1016/J.CHEMOSPHERE.2019.03.143

138. Poniedziałek B, Rzymski P, Kokociński M, Karczewski J (2015) Toxic potencies of metabolite(s) of non-cylindrospermopsin producing Cylindrospermopsis raciborskii isolated from temperate zone in human white cells. Chemosphere 120:608-614. https://doi.org/10.1016/j.chemospher e.2014.09.067

139. Froscio SM, Cannon E, Lau HM, Humpage AR (2009) Limited uptake of the cyanobacterial toxin cylindrospermopsin by Vero cells. Toxicon 54:862-868. https://doi.org/10.1016/j.toxicon.2009.06.019

140. Chong MWK, Wong BSF, Lam PKS et al (2002) Toxicity and uptake mechanism of cylindrospermopsin and lophyrotomin in primary rat hepatocytes. Toxicon 40:205-211

141. Pichardo S, Devesa V, Puerto M et al (2017) Intestinal transport of cylindrospermopsin using the Caco-2 cell line. Toxicol In Vitro 38:142-149. https://doi.org/10.1016/J.TIV.2016.09.021

142. Gutiérrez-Praena D, Pichardo S, Jos Á et al (2012) Biochemical and pathological toxic effects induced by the cyanotoxin Cylindrospermopsin on the human cell line Caco-2. Water Res 46:1566-1575. https://doi. org/10.1016/J.WATRES.2011.12.044

143. Fastner J, Heinze R, Humpage AR et al (2003) Cylindrospermopsin occurrence in two German lakes and preliminary assessment of toxicity and toxin production of Cylindrospermopsis raciborskii (Cyanobacteria) isolates. Toxicon 42:313-321. https://doi.org/10.1016/S0041 $-0101(03) 00150-8$

144. Froscio SM, Fanok S, Humpage AR (2009) Cytotoxicity screening for the cyanobacterial toxin cylindrospermopsin. J Toxicol Environ Health Part A 72:345-349. https://doi.org/10.1080/15287390802529906

145. Poniedziałek B, Rzymski P, Karczewski J (2014) Cylindrospermopsin decreases the oxidative burst capacity of human neutrophils. Toxicon 87:113-119. https://doi.org/10.1016/j.toxicon.2014.05.004

146. Sieroslawska A, Rymuszka A (2015) Cylindrospermopsin induces oxidative stress and genotoxic effects in the fish CLC cell line. J Appl Toxicol 35:426-433. https://doi.org/10.1002/jat.3040

147. Hoiczyk E, Hansel A (2000) Cyanobacterial cell walls: news from an unusual prokaryotic envelope. J Bacteriol 182:1191-1199. https://doi. org/10.1128/JB.182.5.1191-1199.2000

148. Park BS, Lee J-O (2013) Recognition of lipopolysaccharide pattern by TLR4 complexes. Exp Mol Med 45:e66-e66. https://doi.org/10.1038/ emm.2013.97

149. Barton GM, Medzhitov R (2003) Toll-like receptor signaling pathways. Science 300:1524-1525. https://doi.org/10.1126/science.1085536

150. Vaure C, Liu Y (2014) A comparative review of Toll-Like receptor 4 expression and functionality in different animal species. Front Immunol 5:316. https://doi.org/10.3389/fimmu.2014.00316

151. Sansonetti PJ, Di Santo JP (2007) Debugging how bacteria manipulate the immune response. Immunity 26:149-161. https://doi.org/10.1016/j. immuni.2007.02.004

152. Medzhitov R, Janeway CA (2002) Decoding the patterns of self and nonself by the innate immune system. Science 296:298-300. https:// doi.org/10.1126/science.1068883

153. Weise G, Drews G, Jann B, Jann K (1970) Identification and analysis of a lipopolysaccharide in cell walls of the blue-green alga Anacystis nidulans. Arch Mikrobiol 71:89-98. https://doi.org/10.1007/BF00412238 
154. Razziudin S, Siegelman HW, Tornabene TG (1983) Lipopolysaccharides of the cyanobacterium Microcystis aeruginosa. Eur J Biochem 137:333-336. https://doi.org/10.1111/j.1432-1033.1983.tb07833.x

155. Keleti G, Sykora JL (1982) Production and properties of cyanobacterial endotoxins. Appl Environ Microbiol 43:104-109

156. Stewart I, Schluter PJ, Shaw GR (2006) Cyanobacterial lipopolysaccharides and human health-a review. Environ Health 5:7. https://doi. org/10.1186/1476-069X-5-7

157. Bláhová L, Adamovský O, Kubala L et al (2013) The isolation and characterization of lipopolysaccharides from Microcystis aeruginosa, a prominent toxic water bloom forming cyanobacteria. Toxicon 76:187-196

158. Moosová Z, Šindlerová L, Ambrůzová B et al (2019) Lipopolysaccharides from Microcystis cyanobacteria-dominated water bloom and from laboratory cultures trigger human immune innate response. Toxins (Basel) 11:218. https://doi.org/10.3390/toxins11040218

159. Macagno A, Molteni M, Rinaldi A et al (2006) A cyanobacterial LPS antagonist prevents endotoxin shock and blocks sustained TLR4 stimulation required for cytokine expression. J Exp Med 203:1481-1492. https ://doi.org/10.1084/jem.20060136

160. Oliver R, Staples KJ, Heckels J et al (2012) Coadministration of the cyanobacterial lipopolysaccharide antagonist CyP with antibiotic inhibits cytokine production by an in vitro meningitis model infected with Neisseria meningitidis. J Antimicrob Chemother 67:1145-1154. https:// doi.org/10.1093/jac/dks031

161. Molteni M, Bosi A, Rossetti C et al (2018) The effect of cyanobacterial LPS antagonist (CyP) on cytokines and micro-RNA expression induced by Porphyromonas gingivalis LPS. Toxins (Basel) 10:290. https://doi. org/10.3390/toxins10070290

162. D'Hennezel E, Abubucker S, Murphy LO, Cullen TW (2017) Total lipopolysaccharide from the human gut microbiome silences Toll-Like Receptor signaling. mSystems 2:e00046-17. https://doi.org/10.1128/ mSystems.00046-17

163. Arpaia N, Rudensky AY (2014) Microbial metabolites control gut inflammatory responses. Proc Natl Acad Sci U S A 111:2058-2059. https://doi. org/10.1073/pnas.1323183111

164. Durai P, Batool M, Choi S (2015) Structure and effects of cyanobacterial lipopolysaccharides. Mar Drugs 13:4217-4230. https://doi.org/10.3390/ md13074217

165. Carillo S, Pieretti G, Bedini E et al (2014) Structural investigation of the antagonist LPS from the cyanobacterium Oscillatoria planktothrix FP1. Carbohydr Res 388:73-80. https://doi.org/10.1016/j.carres.2013.10.008

166. Gemma S, Molteni M, Rossetti C (2016) Lipopolysaccharides in cyanobacteria: a brief overview. Adv Microbiol 6:391-397. https://doi. org/10.4236/aim.2016.65038

167. Munford RS (2008) Sensing gram-negative bacterial lipopolysaccharides: a human disease determinant? Infect Immun 76:454-465. https:// doi.org/10.1128/IAl.00939-07

168. Miller TR, Beversdorf L, Weirich CA, Bartlett SL (2017) Cyanobacterial toxins of the Laurentian Great Lakes, their toxicological effects, and numerical limits in drinking water. Mar Drugs 15:160. https://doi. org/10.3390/md15060160

169. Abreu MT, Thomas LS, Arnold ET et al (2003) TLR signaling at the intestinal epithelial interface. J Endotoxin Res 9:322-330. https://doi. org/10.1179/096805103225002593

170. Price AE, Shamardani K, Lugo KA et al (2018) A map of Toll-like receptor expression in the intestinal epithelium reveals distinct spatial, cell typespecific, and temporal patterns. Immunity 49:560-575.e6. https://doi. org/10.1016/j.immuni.2018.07.016

171. Bäckhed F, Hornef M (2003) Toll-like receptor 4-mediated signaling by epithelial surfaces: necessity or threat? Microbes Infect 5:951-959. https ://doi.org/10.1016/S1286-4579(03)00189-8

172. Abreu MT, Fukata M, Arditi M (2005) TLR signaling in the gut in health and disease. J Immunol 174:4453-4460. https://doi.org/10.4049/JIMMU NOL.174.8.4453

173. Mayer AMS, Clifford JA, Aldulescu M et al (2011) Cyanobacterial Microcystis aeruginosa lipopolysaccharide elicits release of superoxide anion, thromboxane B2, cytokines, chemokines, and matrix metalloproteinase-9 by rat microglia. Toxicol Sci 121:63-72. https://doi.org/10.1093/ toxsci/kfr045

174. Mayer AMS, Murphy J, MacAdam D et al (2016) Classical and alternative activation of cyanobacterium Oscillatoria sp. lipopolysaccharide-treated rat microglia in vitro. Toxicol Sci 149:484-495. https://doi.org/10.1093/ toxsci/kfv251

175. Klemm LC, Czerwonka E, Hall ML et al (2018) Cyanobacteria Scytonema javanicum and Scytonema ocellatum lipopolysaccharides elicit release of superoxide anion, matrix-metalloproteinase-9, cytokines and chemokines by rat microglia in vitro. Toxins (Basel) 10:130. https://doi. org/10.3390/toxins10040130

176. Funari E, Testai $E$ (2008) Human health risk assessment related to cyanotoxins exposure. Crit Rev Toxicol 38:97-125. https://doi. org/10.1080/10408440701749454

177. Bell SG, Codd GA (1994) Cyanobacterial toxins and human health. Rev Med Microbiol 5:256-264. https://doi.org/10.1097/00013542-19941 0000-00005

178. Stal LJ, Albertano P, Bergman B et al (2003) BASIC: baltic Sea cyanobacteria. An investigation of the structure and dynamics of water blooms of cyanobacteria in the Baltic Sea-responses to a changing environment. Cont Shelf Res 23:1695-1714. https://doi.org/10.1016/J. CSR.2003.06.001

179. Ploug H (2008) Cyanobacterial surface blooms formed by Aphanizomenon sp. and Nodularia spumigena in the Baltic Sea: small-scale fluxes, pH, and oxygen microenvironments. Limnol Oceanogr 53:914-921

180. Faltermann S, Prétôt R, Pernthaler J, Fent K (2016) Comparative effects of nodularin and microcystin-LR in zebrafish: 1. Uptake by organic anion transporting polypeptide Oatp1d1 (Slco1d1). Aquat Toxicol 171:69-76. https://doi.org/10.1016/J.AQUATOX.2015.11.016

181. Meili N, Christen V, Fent K (2016) Nodularin induces tumor necrosis factor-alpha and mitogen-activated protein kinases (MAPK) and leads to induction of endoplasmic reticulum stress. Toxicol Appl Pharmacol 300:25-33. https://doi.org/10.1016/J.TAAP.2016.03.014

182. Bagu JR, Sykes BD, Craig MM, Holmes CFB (1997) A molecular basis for different interactions of marine toxins with protein phosphatase-1. Molecular models for bound motuporin, microcystins, okadaic acid, and calyculin A. J Biol Chem 272:5087-5097

183. Koreivienè J, Anne O, Kasperovičienè J, Burškytè V (2014) Cyanotoxin management and human health risk mitigation in recreational waters. Environ Monit Assess 186:4443-4459. https://doi.org/10.1007/s1066 1-014-3710-0

184. Weirich CA, Miller TR (2014) Freshwater harmful algal blooms: toxins and children's health. Curr Probl Pediatr Adolesc Health Care 44:2-24. https://doi.org/10.1016/j.cppeds.2013.10.007

185. Otten TG, Paerl HW (2015) Health effects of toxic cyanobacteria in U.S. drinking and recreational waters: our current understanding and proposed direction. Curr Environ Health Rep 2:75-84. https://doi. org/10.1007/s40572-014-0041-9

186. Ersmark K, Del Valle JR, Hanessian S (2008) Chemistry and biology of the aeruginosin family of serine protease inhibitors. Angew Chemie Int Ed 47:1202-1223. https://doi.org/10.1002/anie.200605219

187. Welker M, Von Döhren H (2006) Cyanobacterial peptides_nature's own combinatorial biosynthesis. FEMS Microbiol Rev 30:530-563. https:// doi.org/10.1111/j.1574-6976.2006.00022.x

188. Fewer DP, Jokela J, Paukku E et al (2013) New structural variants of aeruginosin produced by the toxic bloom forming cyanobacterium Nodularia spumigena. PLoS ONE 8:e73618. https://doi.org/10.1371/ journal.pone.0073618

189. Faltermann S, Zucchi S, Kohler E et al (2014) Molecular effects of the cyanobacterial toxin cyanopeptolin (CP1020) occurring in algal blooms: global transcriptome analysis in zebrafish embryos. Aquat Toxicol 149:33-39. https://doi.org/10.1016/j.aquatox.2014.01.018

190. Janssen EM-L (2019) Cyanobacterial peptides beyond microcystins-a review on co-occurrence, toxicity, and challenges for risk assessment. Water Res 151:488-499. https://doi.org/10.1016/J.WATRES.2018.12.048

191. Oftedal L, Myhren L, Jokela J et al (2012) The lipopeptide toxins anabaenolysin A and B target biological membranes in a cholesteroldependent manner. Biochim Biophys Acta Biomembr 1818:3000-3009. https://doi.org/10.1016/j.bbamem.2012.07.015

192. Hrouzek P, Kuzma M, Černý J et al (2012) The cyanobacterial cyclic lipopeptides puwainaphycins $F / G$ are inducing necrosis via cell membrane permeabilization and subsequent unusual actin relocalization. Chem Res Toxicol 25:1203-1211. https://doi.org/10.1021/tx300044t 
193. Vašíček O, Hrouzek P, Hájek J et al (2017) The effects of puwainaphycins F on Caco-2 cell line as a model of the intestinal barrier. Toxicol Lett 280:S86. https://doi.org/10.1016/j.toxlet.2017.07.238

194. Humpage AR, Falconer IR, Bernard C et al (2012) Toxicity of the cyanobacterium Limnothrix AC0243 to male Balb/c mice. Water Res 46:1576-1583. https://doi.org/10.1016/j.watres.2011.11.019

195. Saker ML, Nogueira ICG, Vasconcelos VM et al (2003) First report and toxicological assessment of the cyanobacterium Cylindrospermopsis raciborskii from Portuguese freshwaters. Ecotoxicol Environ Saf 55:243-250. https://doi.org/10.1016/S0147-6513(02)00043-X

196. Hirahashi T, Matsumoto M, Hazeki K et al (2002) Activation of the human innate immune system by Spirulina: augmentation of interferon production and NK cytotoxicity by oral administration of hot water extract of Spirulina platensis. Int Immunopharmacol 2:423-434
197. Bernardová K Babica P, Maršálek B Bláha L (2008) Isolation and endotoxin activities of lipopolysaccharides from cyanobacterial cultures and complex water blooms and comparison with the effects of heterotrophic bacteria and green alga. J Appl Toxicol 28:72-77. https://doi. org/10.1002/jat.1257

198. Falconer IR (2001) Toxic cyanobacterial bloom problems in Australian waters: risks and impacts on human health. Phycologia 40:228-233. https://doi.org/10.2216/i0031-8884-40-3-228.1

\section{Publisher's Note}

Springer Nature remains neutral with regard to jurisdictional claims in published maps and institutional affiliations.

\section{Submit your manuscript to a SpringerOpen ${ }^{\circ}$ journal and benefit from:}

- Convenient online submission

- Rigorous peer review

- Open access: articles freely available online

- High visibility within the field

- Retaining the copyright to your article

Submit your next manuscript at $\boldsymbol{\nabla}$ springeropen.com 